\title{
DEVELOPMENT OF A SUPERNATE SIMULANT FOR HANFORD TANK 241-AN-102 WASTE (U)
}

February 2003

Immobilization Technology Section

Savanhah River Technology Center

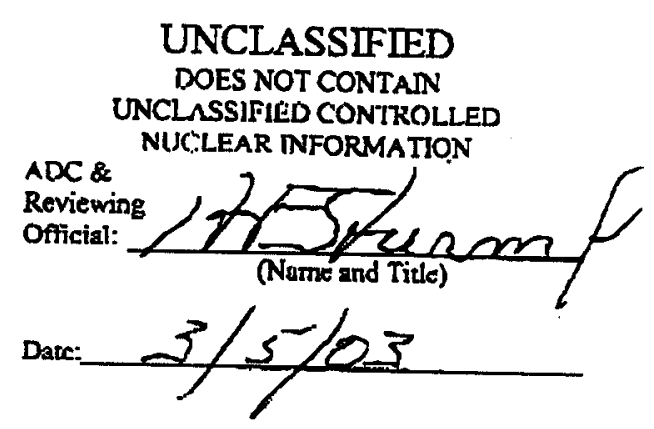

ADDIIIONAL APPROVAL, IF APPLICABLE:

Onicial:

R\&T Manager, RPP Hanfond

Dare:

Westinghouse Savannah River Company Savannah River Site

Aiken, SC 29808

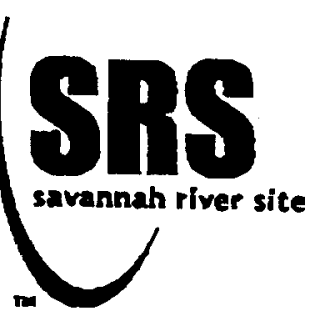


This document was prepared in conjunction with work accomplished under Contract No. DE-AC09-96SR18500 with the U. S. Department of Energy.

\section{DISCLAIMER}

This report was prepared as an account of work sponsored by an agency of the United States Government. Neither the United States Government nor any agency thereof, nor any of their employees, makes any warranty, express or implied, or assumes any legal liability or responsibility for the accuracy, completeness, or usefulness of any information, apparatus, product or process disclosed, or represents that its use would not infringe privately owned rights. Reference herein to any specific commercial product, process or service by trade name, trademark, manufacturer, or otherwise does not necessarily constitute or imply its endorsement, recommendation, or favoring by the United States Government or any agency thereof. The views and opinions of authors expressed herein do not necessarily state or reflect those of the United States Government or any agency thereof.

This report has been reproduced directly from the best available copy.

Available for sale to the public, in paper, from: U.S. Department of Commerce, National Technical Information Service, 5285 Port Royal Road, Springfield, VA 22161, phone: (800) 553-6847, fax: (703) 605-6900

email: orders@ntis.fedworld.gov

online ordering: http://www.ntis.gov/help/index.asp

Available electronically at http://www.osti.gov/bridge

Available for a processing fee to U.S. Department of Energy and its contractors, in paper, from: U.S. Department of Energy, Office of Scientific and Technical Information, P.O. Box 62, Oak Ridge, TN 37831-0062,

phone: (865)576-8401,

fax: (865)576-5728

email: $\underline{\text { reports@ adonis.osti.gov }}$ 
Key Words:

River Protection Project

Entrained Solids Simulant

Retention:

\#Permanent\#

Key WTP R\&T References:

S141 - Simulant Development

\title{
DEVELOPMENT OF A SUPERNATE SIMULANT FOR HANFORD TANK 241-AN-102 WASTE (U)
}

\author{
Russell E. Eibling, Building 999-W
}

\section{Issue Date: February 2003}

Westinghouse Savannah River Company

Savannah River Site

Aiken, SC 29808

Prepared for the U.S. Department of Energy Under Contract Number DE-AC09-96SR18500

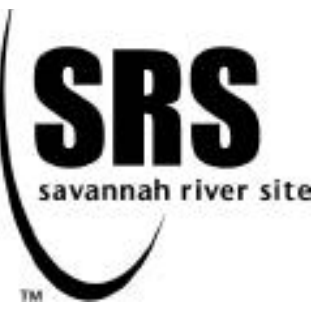


This page intentionally left blank 
WSRC-TR-2002-00040, REV. 0, SRT-RPP-2002-00012. REV. 0

\section{TABLE OF CONTENTS}

TABLE OF CONTENTS ............................................................................................................. v

LIST OF FIGURES ……...................................................................................................................... vii

LIST OF TABLES .................................................................................................................................... vii

LIST OF ACRONYMS .................................................................................................................... ix

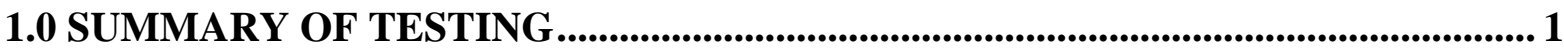

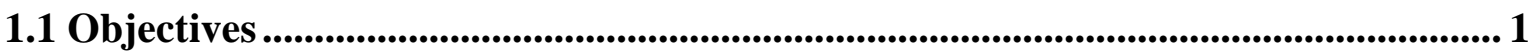

1.2 Conduct of Testing .............................................................................................................................. 1

1.3 Results and Performance against Objectives......................................................................... 1

1.4 Quality Requirements ....................................................................................................................... 2

1.5 Issues .......................................................................................................................................... 2

2.0 DISCUSSION ….......................................................................................................................... 2

2.1 Introduction and Background.................................................................................................. 2

2.2 Simulant Development ....................................................................................................................... 3

2.2.1 Supernate Simulant........................................................................................................................ 3

2.2.2 Entrained Solids Simulant.................................................................................................... 17

2.2.3 Simulant Validation ................................................................................................................ 19

2.2.3.1 Chemical Composition Validation........................................................................... 19

2.2.3.2 Physical Property Validation.................................................................................. 24

2.2.3.2.1 Density .......................................................................................................................... 24

2.2.3.2.2 Rheology ……................................................................................................................. 25

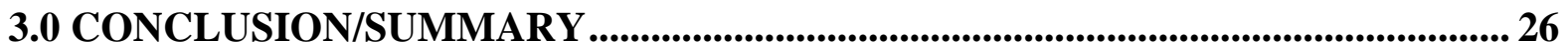

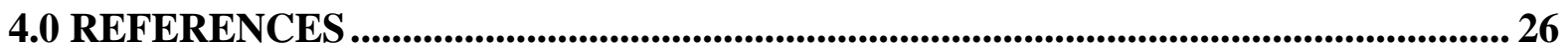


WSRC-TR-2002-00040, REV. 0, SRT-RPP-2002-00012. REV. 0

APPENDIX A: AN-102 SUPERNATE AND ENTRAINED SOLIDS SIMULANT

PREPARATION PROCEDURE............................................................................... 29

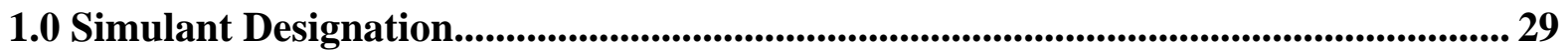

2.0 Simulant Waste Stream Composition and Unit Operation Usage ............................ 29

2.1 Characterization Data Description ....................................................................................... 29

2.2 Flowsheet Operation for Which the Simulant was Developed.................................... 29

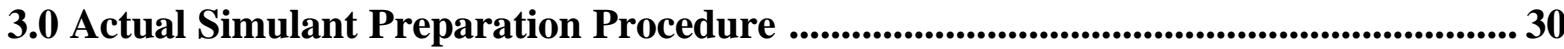

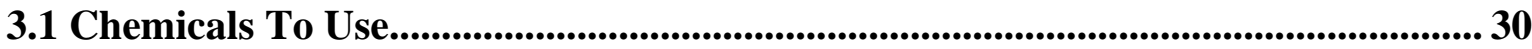

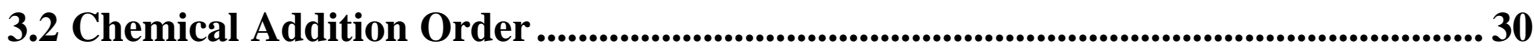

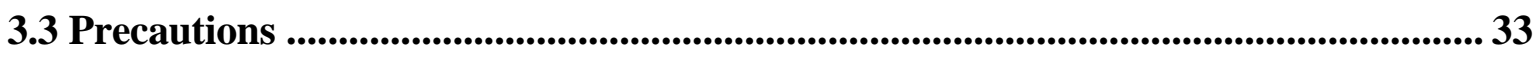

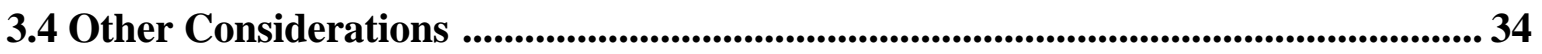

4.0 Key Characteristics and Limitations of AN-102 Supernate Simulant ......................... 34

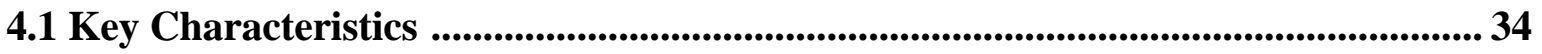

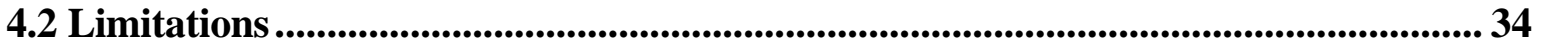

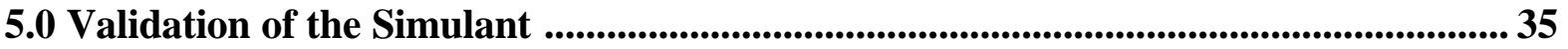

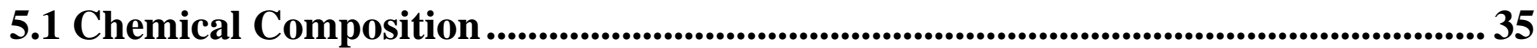

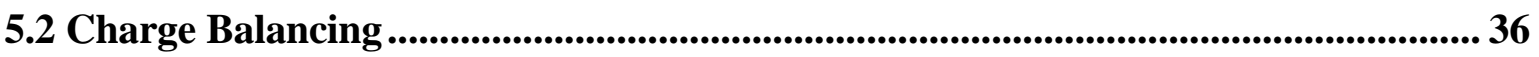

6.0 Simulant Properties Compa red to Actual Waste Properties.......................................... 37

7.0 Simulant Development Organization................................................................... 37

8.0 References..................................................................................................................................... 38 


\section{LIST OF FIGURES}

Figure 1 Soluble Lanthanum versus Sodium Gluconate .............................................. 9

Figure 2 Soluble Iron versus Sodium Gluconate ........................................................... 9

Figure 3 Soluble Neodymium versus Sodium Gluconate ............................................. 10

Figure 4 Soluble Lead versus Sodium Gluconate ...................................................... 10

Figure 5 Soluble Manganese versus Sodium Gluconate .............................................. 11

Figure 6 Solids filtered from AN-102 simulant at 6.5 Molar Na....................................... 21

Figure 7 AN-102 Supernate Simulant Flow Curve Compared to Actual Waste ................... 25

\section{LIST OF TABLES}

Table 1 Recent Sample Analyses of AN-102 Supernate ............................................... 3

Table 2 AN-102 Sample Results Diluted to 6.5 Molar Na Basis ........................................ 5

Table 3 Analytical Basis for Inorganic Composition of AN-102 Simulant .......................... 6

Table 4 Organic Basis for the AN-102 Supernate Simulant ........................................... 7

Table 5 Calculated Sodium Gluconate Requirement for AN-102 Simulant at 9.5 Molar Na11

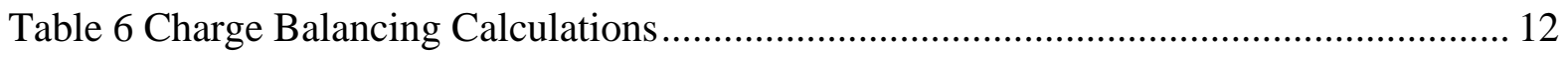

Table 7 Revised Nitrate and Nitrite Concentrations from Charge Balancing ..................... 13

Table 8 AN-102 Supernate Simulant Formulation at 6.5 Molar Na................................... 13

Table 9 AN-102 Supernate Simulant Formulation at 9.5 Molar Na.................................. 14 
Table 10 Procedure for One Liter of AN-102 Supernate Simulant at 6.5 Molar Na............. 15

Table 11 Basis for AN-102 Unwashed Entrained Solids............................................... 17

Table 12 Recipe for Unwashed AN-102 Entrained Solids Simulant.................................. 18

Table 13 AN-102 Simulant Basis Compared to AN-102 Composition from Reference $12 \ldots 19$

Table 14 Analytical Results for the Undiluted AN-102 Simulant (9.5 Molar Na) ............... 22

Table 15 Analytical Results for the AN-102 Simulant at 6.5 M Na................................. 23

Table 16 Supernate Density at 25 Celsius ....................................................................... 24

Table 17 Simulant Density Based on Empirical Equation................................................ 25

Table 18 Viscosity of AN-102 Simulant and Actual AN-102 Supernate at 25 Celsius ........ 26 


\section{LIST OF ACRONYMS}

$\mathrm{cP} \quad$ Centipoise (equivalent to milliPascat-seconds)

ED3A Ethylenediaminetriacetic acid

EDTA Ethylenediaminetetracetic acid

GCMS Gas Chromatograph - Mass spectrometer

HEDTA N-(2-hydroxyethyl)ethylenediaminetriacetic acid

HPLC High Performance Liquid Chromatography

IC Ion Chromatography

ICP-ES Inductively Coupled Plasma - Emission Spectrometer

IDA Iminodiacetic acid

IEC Ion Exclusion Chromatography

MDL Method Detection Limit

MSDS Material Safety Data Sheet

NTA Nitrilotriacetic acid

RPP-WTP River Protection Project - Waste Treatment Plant

SRTC Savannah River Technology Center

TFCOUP Tank Farm Contractor Operation and Utilization Plan, Rev 3A

TIC Total Inorganic Carbon

TOC Total Organic Carbon

XRD X-ray Diffraction analysis 


\subsection{SUMMARY OF TESTING}

\subsection{Objectives}

Envelope C waste includes Hanford Tank 241-AN-102, which contains high levels of organic complexants and high levels of soluble aluminum. Supporting SRTC studies of RPP-WTP processes require the use of a simulant for AN-102 supernate. A simulant has been developed that contains the levels of soluble transition metals observed in tank AN-102. Development of the simulant was based on the most recent characterizations of AN-102 waste. Estimating the amount of gluconate ion present in the AN-102 supernate was necessary to produce the correct soluble metals concentrations. The simulant formulation is based on the nominal composition of Tank AN-102 supernate at 9.5 molar sodium and diluted to 6.5 molar sodium concentrations.

The primary uses for the simulant will be:

- Precipitation/Filtration studies (lab, bench and pilot-scale)

- LAW evaporation and antifoam studies.

Additional applications may be identified as the project proceeds.

\subsection{Conduct of Testing}

The development of the AN-102 simulant involved identifying an analytical basis for the waste composition. Charge balancing the basis composition requires using a method acceptable to the programs planning to use the simulant. Bench-scale experiments on metal solubility as a function of sodium gluconate concentration were conducted to establish a basis for the gluconate concentration. Additional tests were performed to determine the sequence of chemical addition to prevent unwanted reactions. The final step was measurement of the physical properties of the simulant for use in developing large batch recipes and for comparison with actual waste properties.

\subsection{Results and Performance against Objectives}

A formulation for a supernate simulant has been developed to represent waste from Hanford Tank 241-AN-102. The simulant is designed to reproduce the nominal chemical composition of the supernate at 9.5 molar sodium (undiluted) and when the supernate is diluted to 6.5 molar sodium concentration. The simulant also includes a formulation to represent the unwashed entrained solids expected in the undiluted supernate. 


\subsection{Quality Requirements}

This work was conducted in accordance with the RPP-WTP QA requirements specified for work conducted by SRTC as identified in DOE IWO MOSRLE60. SRTC has provided matrices to WTP demonstrating compliance of the SRTC QA program with the requirements specified by WTP. Specific information regarding the compliance of the SRTC QA program with RW-0333P, Revision 10, NQA-1 1989, Part 1, Basic and Supplementary Requirements and NQA-2a 1990, Subpart 2.7 is contained in these matrices.

The simulant development supports Sr/TRU precipitation/filtration, evaporation and ion exchange testing as specified in the following task plans:

- Task Technical and Quality Assurance Plan In Support of RPP-WTP Pilot-Scale Precipitation Testing. ${ }^{1}$

- Task Technical and Quality Assurance Plan for AN-102 Simulant Sr/TRU Precipitation and Ultrafiltration. ${ }^{2}$

- Evaluation of Post-Filtration Precipitation Mechanism. ${ }^{3}$

- Complexant Identification in Hanford Waste Simulant Sr/TRU Filtrate. ${ }^{4}$

- Task Technical and Quality Assurance Plan for - LAW Evaporation: Antifoam/Defoamer Testing for Low Activity Waste Solution. ${ }^{5}$

\subsection{Issues}

The development of the AN-102 simulant has not identified any issues for design or operation of the River Protection Project - Waste Treatment Plant (RPP-WTP).

\subsection{DISCUSSION}

\subsection{INTRODUCTION AND BACKGROUND}

Research and testing of the proposed processes for RPP-WTP typically requires the use of waste simulants designed to duplicate the chemical and physical properties of the waste. The complexity of the specific simulant is a function of the specific waste and of the process to be tested. Envelope C wastes such as the supernate from Hanford tanks 241-AN-107 and 241AN-102, are complex mixtures of metal ions, complexants and other anions. The Savannah River Technology Center has been asked to develop a simulant for the supernate from Tank 241-AN-102 based upon recent waste characterization results. The simulant development 
supports Sr/TRU precipitation/filtration, evaporation and ion exchange testing previously cited in section 1.4 .

\subsection{SIMULANT DEVELOPMENT}

\subsubsection{Supernate Simulant}

The supernate within tank 241-AN-102 is known as complex concentrate because it contains high levels of complexed metals. These organic complexing agents result in the supernate having the high Total Organic Carbon value reported in waste characterization reports. The difference between tank AN-102 supernate and the previously developed AN-107 simulant (also Envelope C) is that the AN-102 supernate has a relatively high hydroxide level and therefore a high soluble aluminate concentration instead of the very low hydroxide level observed in previous AN-107 waste samples. A successful supernate simulant for AN-102 must have sufficient complexing agents present to duplicate the soluble metal concentrations observed within the waste as well as a hydroxide concentration sufficient to support the required soluble aluminate. As previously mentioned, the AN-102 simulant will be used for testing the following processes: ion exchange, Sr/TRU precipitation, pilot-scale crossflow filtration and antifoam selection for evaporator operation.

The analytical basis for the simulant composition for most of the waste components comes from recent waste samples. ${ }^{6-9}$ The final waste component, sodium gluconate, was reported as a less than value ( $<1000 \mathrm{mg} /$ Liter) while process history indicates that sodium gluconate was used during Hanford B plant processing. Sodium gluconate was used as a sequestering agent to prevent metal precipitation during B plant processing. An essential materials document from the 1970's indicates the consumption of 10,000 pounds per year of sodium gluconate (Reference 18).

The sample analyses used in formulating the AN-102 simulant are listed in Table 1. The value shown for ethylenediaminetetraacetic acid (EDTA) for Reference 7 is based upon the sum of the maximum values observed for EDTA and for ethylenediaminetriacetic acid (ED3A). The concentration for cesium was based on summing the isotopic results from an analysis by inductively coupled plasma - mass spectrometry. The carbonate concentration was calculated from the TIC measurement.

Table 1 Recent Sample Analyses of AN-102 Supernate

\begin{tabular}{|c|c|c|c|c|c|}
\hline & $\begin{array}{c}\text { Reference 6 } \\
\text { SRTC } \\
\text { Sampled 8/98 }\end{array}$ & $\begin{array}{c}\text { Reference 7 } \\
\text { Battelle, } \\
\text { Sampled 8/2000 }\end{array}$ & $\begin{array}{c}\text { Reference 8 } \\
\text { Hanford } \\
\text { Sampled 2/98 }\end{array}$ & $\begin{array}{c}\text { Reference 9 } \\
\text { Hanford } \\
\text { Sampled 1994-1995 }\end{array}$ & Average \\
\hline Component & mg/Liter & mg/Liter & mg/Liter & mg/Liter & mg/Liter \\
\hline Acetate & 993 & NM & NM & 15100 & 993 \\
\hline Aluminum & 14608 & 12300 & 15933 & NM & 144 \\
\hline Ammonium & NM & 152 & 132 & NM & 41 \\
\hline Boron & 39 & NM & 43 & & 1485 \\
\hline
\end{tabular}


WSRC-TR-2002-00040, REV. 0, SRT-RPP-2002-00012. REV. 0

\begin{tabular}{|c|c|c|c|c|c|}
\hline & $\begin{array}{c}\text { Reference 6 } \\
\text { SRTC } \\
\text { Sampled 8/98 }\end{array}$ & $\begin{array}{c}\text { Reference } 7 \\
\text { Battelle, } \\
\text { Sampled 8/2000 }\end{array}$ & $\begin{array}{c}\text { Reference } 8 \\
\text { Hanford } \\
\text { Sampled 2/98 }\end{array}$ & $\begin{array}{c}\text { Reference 9 } \\
\text { Hanford } \\
\text { Sampled 1994-1995 }\end{array}$ & Average \\
\hline Component & mg/Liter & mg/Liter & mg/Liter & mg/Liter & mg/Liter \\
\hline Cadmium & 60 & 62 & 67 & NM & 63 \\
\hline Calcium & 491 & 489 & 518 & 434 & 483 \\
\hline Carbonate & 72944 & 54958 & 68281 & 65950 & 65533 \\
\hline Cesium & 20 & 16 & NM & NM & 18 \\
\hline Chloride & 3803 & 4800 & 4303 & 3810 & 4179 \\
\hline Chromium & 252 & 215 & 300 & 297 & 266 \\
\hline Cobalt & 4 & NM & LT & NM & 4 \\
\hline Copper & 24 & 23 & 26 & NM & 24 \\
\hline $\begin{array}{c}\text { Ethylenediaminetetraacetic } \\
\text { acid }\end{array}$ & 9221 & 2780 & NM & NM & 6001 \\
\hline \begin{tabular}{c|} 
Fluoride \\
\end{tabular} & 2190 & LT & 1837 & 1860 & 1962 \\
\hline Formate & 10760 & 8000 & NM & NM & 9380 \\
\hline Glycolate & 13020 & 10500 & NM & NM & 11760 \\
\hline Hydroxide & 22020 & 4300 & 2580 & 3610 & 8128 \\
\hline Iron & 35 & 37 & 50 & 50.9 & 43 \\
\hline Lanthanum & 14 & 16 & LT & NM & 15 \\
\hline Lead & 182 & 186 & 185 & NM & 184 \\
\hline Manganese & 17 & 17 & 26 & 39.1 & 25 \\
\hline Molybdenum & 58 & NM & 55 & NM & 56 \\
\hline Neodymium & NM & 32 & NM & NM & 32 \\
\hline $\begin{array}{c}\mathrm{n}-(2- \\
\text { Hydroxyethyl)ethylenedia } \\
\text { minetriacetic acid }\end{array}$ & 7105 & 150 & NM & NM & 3628 \\
\hline Nickel & 407 & 416 & 445 & 381 & 412 \\
\hline Nitrate & 190132 & 221000 & 233667 & 225000 & 217450 \\
\hline Nitrite & 82390 & 85400 & 92967 & 82600 & 85839 \\
\hline Oxalate & 591 & 460 & NM & $\mathrm{NM}$ & 526 \\
\hline Phosphate & 4975 & 5580 & 6080 & 4820 & 5364 \\
\hline Phosphorus & 1900 & 1820 & 1803 & 1610 & 1783 \\
\hline Potassium & 2190 & 1980 & 2373 & 3880 & 2606 \\
\hline Rubidium & NM & 8.74 & NM & NM & 9 \\
\hline Silicon & 12 & 235 & LT & LT & 124 \\
\hline Sodium & 234500 & 184000 & 219000 & 240000 & 219375 \\
\hline Strontium & 2.9 & 2.3 & LT & NM & 3 \\
\hline Sulfate & 12910 & 16900 & 15533 & 13800 & 14786 \\
\hline Sulfur & NM & NM & 5673 & 4750 & 5212 \\
\hline TIC & 14600 & 11000 & 13667 & 13200 & 13117 \\
\hline TOC & 27015 & 29300 & 24567 & 26200 & 26770 \\
\hline Tungsten & NM & NM & 201 & NM & 201 \\
\hline Zinc & 6 & LT & LT & $\mathrm{NM}$ & 6 \\
\hline Zirconium & 17 & 8.2 & 10 & NM & 12 \\
\hline \multicolumn{6}{|l|}{ Additional Organics } \\
\hline Nitrilotriacetic Acid & NM & 260 & NM & NM & 260 \\
\hline Citric Acid & 5965 & 4400 & NM & $\mathrm{NM}$ & 5183 \\
\hline Iminodiacetic Acid & 3880 & 4500 & NM & $\mathrm{NM}$ & 4190 \\
\hline Succinic Acid & NM & 36 & NM & NM & 36 \\
\hline
\end{tabular}

$\mathrm{NM}=$ Not Measured, $\mathrm{LT}=$ Less than, NA = Not applicable 
WSRC-TR-2002-00040, REV. 0, SRT-RPP-2002-00012. REV. 0

To provide a consistent basis for comparison, all of the samples were mathematically diluted to 6.5 molar $\mathrm{Na}$ based upon their specific sodium measurements. The result of the dilution is shown in Table 2.

Table 2 AN-102 Sample Results Diluted to 6.5 Molar Na Basis

\begin{tabular}{|c|c|c|c|c|c|c|c|}
\hline & Reference 6 & Reference 7 & Reference 8 & Reference 9 & Average & $\begin{array}{c}\text { Diluted } \\
\text { Simulant } \\
\text { Basis }\end{array}$ & $\begin{array}{c}\text { Undiluted } \\
\text { Simulant Basis }\end{array}$ \\
\hline Component & mg/Liter & mg/Liter & mg/Liter & mg/Liter & mg/Liter & mg/Liter & mg/Liter \\
\hline Acetate & 633 & NM & NM & NM & 633 & 630 & 925 \\
\hline Aluminum & 9309 & 9989 & 10872 & 9402 & 9893 & 10000 & 14682 \\
\hline Ammonium & NM & 123 & 90 & NM & 107 & 120 & 176 \\
\hline Boron & 25 & $\mathrm{NM}$ & 29 & NM & 27 & 30 & 44 \\
\hline Cadmium & 38 & 50 & 46 & $\mathrm{NM}$ & 45 & 50 & 73 \\
\hline Calcium & 313 & 397 & 353 & 270 & 333 & 400 & 587 \\
\hline Carbonate & 46483 & 44634 & 46591 & 41063 & 44693 & 44714 & 65650 \\
\hline Cesium & 13 & 13 & NM & NM & 13 & 13 & 19 \\
\hline Chloride & 2423 & 3898 & 2936 & 2372 & 2908 & 3900 & 5726 \\
\hline Chromium & 161 & 175 & 205 & 185 & 181 & 205 & 301 \\
\hline Cobalt & 3 & NM & LT & NM & 3 & 3 & 4 \\
\hline Copper & 15 & 19 & 18 & $\mathrm{NM}$ & 17 & 20 & 29 \\
\hline $\begin{array}{l}\text { Ethylenediamine- } \\
\text { tetraacetic acid }\end{array}$ & 5876 & 2258 & NM & NM & 4067 & 2260 & 3318 \\
\hline Fluoride & 1396 & LT & 1253 & 1158 & 1269 & 1400 & 2055 \\
\hline Formate & 6857 & 6497 & NM & NM & 6677 & 6860 & 10072 \\
\hline Glycolate & 8297 & 8527 & NM & NM & 8412 & 8530 & 12524 \\
\hline Hydroxide & 14032 & 3492 & 1760 & 2248 & 5383 & 5500 & 8075 \\
\hline Iron & 22 & 30 & 34 & 32 & 30 & 34 & 50 \\
\hline Lanthanum & 9 & 13 & LT & NM & 11 & 13 & 19 \\
\hline Lead & 116 & 151 & 126 & NM & 131 & 151 & 222 \\
\hline Manganese & 11 & 14 & 18 & 24 & 17 & 24 & 35 \\
\hline Molybdenum & 37 & NM & 37 & NM & 37 & 37 & 54 \\
\hline Neodymium & NM & 26 & NM & $\mathrm{NM}$ & 26 & 26 & 38 \\
\hline \begin{tabular}{|c|}
$\mathrm{n}-(2-$ \\
Hydroxyethyl)ethylen \\
ediaminetriacetic acid
\end{tabular} & 4528 & 122 & NM & NM & 2325 & 300 & 440 \\
\hline \begin{tabular}{|l|} 
Nickel \\
\end{tabular} & 259 & 338 & 304 & 237 & 285 & 340 & 499 \\
\hline Nitrate & 121160 & 179483 & 159441 & 140094 & 150045 & 160000 & 234913 \\
\hline Nitrite & 52502 & 69357 & 63435 & 51430 & 59181 & 63000 & 92497 \\
\hline Oxalate & 377 & 374 & NM & NM & 375 & 377 & 554 \\
\hline Phosphate & 3170 & 4532 & 4149 & 3001 & 3713 & 4500 & 6607 \\
\hline Phosphorus & 1211 & 1478 & 1230 & 1002 & 1230 & 1468 & 2155 \\
\hline Potassium & 1396 & 1608 & 1619 & 2416 & 1760 & 1620 & 2378 \\
\hline Rubidium & NM & 7 & NM & NM & 7 & 7 & 10 \\
\hline Silicon & 8 & 191 & LT & LT & 99 & 8 & 12 \\
\hline Sodium & 149434 & 149434 & 149434 & 149434 & 149434 & 149434 & 219400 \\
\hline Strontium & 2 & 2 & LT & $\mathrm{NM}$ & 2 & 2 & 3 \\
\hline Sulfate & 8227 & 13725 & 10599 & 8592 & 10286 & 10290 & 15108 \\
\hline Sulfur & NM & NM & 3871 & 2958 & 3414 & 3434 & 5042 \\
\hline TIC & 9304 & 8934 & 9325 & 8219 & 8945 & 8950 & 13140 \\
\hline TOC & 17215 & 23796 & 16763 & 16313 & 18522 & 18522 & 27194 \\
\hline
\end{tabular}


WSRC-TR-2002-00040, REV. 0, SRT-RPP-2002-00012. REV. 0

\begin{tabular}{|c|c|c|c|c|c|c|c|}
\hline & Reference 6 & Reference 7 & Reference 8 & Reference 9 & Average & $\begin{array}{c}\text { Diluted } \\
\text { Simulant } \\
\text { Basis }\end{array}$ & $\begin{array}{c}\text { Undiluted } \\
\text { Simulant Basis }\end{array}$ \\
\hline Component & $\mathbf{m g / L i t e r}$ & $\mathbf{m g} /$ Liter & $\mathbf{m g / L i t e r}$ & $\mathbf{m g} /$ Liter & $\mathbf{m g / L i t e r}$ & $\mathbf{m g / L i t e r}$ & mg/Liter \\
\hline Tungsten & NM & NM & 137 & NM & 137 & 137 & 201 \\
\hline Zinc & 4 & LT & LT & NM & 4 & 4 & 6 \\
\hline Zirconium & 11 & 7 & 7 & NM & 8 & 11 & 16 \\
\hline & & & & & & & \\
\hline Additional Organics & & & & & & & \\
\hline Nitrilotriacetic Acid & NM & 211 & NM & NM & 211 & 211 & 310 \\
\hline Citric Acid & 3801 & 3573 & NM & NM & 3687 & 3800 & 5579 \\
\hline Iminodiacetic Acid & 2473 & 3655 & NM & NM & 3064 & 3655 & 5366 \\
\hline Succinic Acid & NM & 29 & NM & NM & 29 & 29 & 43 \\
\hline Dilution Factor & 0.637 & 0.812 & 0.682 & 0.623 & NA & NA & 1.468 \\
\hline
\end{tabular}

$\mathrm{NM}=$ Not Measured, LT $=$ Less than, NA = Not applicable

The basis for the simulant is shown in the columns labeled "Diluted Simulant Basis" and "Undiluted Simulant Basis". The value for sodium for the undiluted supernate is based on the average of all four of the sample analyses. The values used for the major waste components (greater than $500 \mathrm{mg} / \mathrm{L}$ ) were selected to represent the most recent sample analyses (References 6, 7, and 8). For the minor waste components ( $<500 \mathrm{mg} / \mathrm{L})$, the value used was the maximum observed over the four samples. The organic composition is based primarily on the latest sample analysis (Reference 7) as requested by the project, supplemented as needed from the other samples. The value shown from Reference 7 for Ethylenediaminetetraacetate (EDTA) concentration is the sum of the maximum values observed for EDTA and for ethylenediaminetriacetate (ED3A) concentrations. The value for $\mathrm{N}$-(2-hydroxyethyl)ethylenediaminetriacetic acid (HEDTA) shown in Table 1 from Reference 7 was set to the method detection limit (MDL) since the complexant is expected to be present in the AN-102 supernate. To allow for some uncertainty and to reflect the preliminary status of the analytical method used, the basis value for HEDTA was set at twice the MDL. The organic compounds included in the tables is based on the commercially available compounds that are either complexing agents, organic degradation products that are complexing agents, known organic additives from Hanford processes, or major organic radiolysis products.

The analytical basis derived as explained above is listed in Table 3 and Table 4. Table 3 lists the inorganic composition undiluted (9.5 molar $\mathrm{Na}$ ) and diluted (6.5 molar $\mathrm{Na}$ ) used to create the simulant.

Table 3 Analytical Basis for Inorganic Composition of AN-102 Simulant

\begin{tabular}{|c|c|c|c|c|}
\hline & \multicolumn{2}{|c|}{ Undiluted } & \multicolumn{2}{c|}{ Diluted to 6.5 M Na } \\
\hline Component & mg/Liter & Moles/Liter & mg/Liter & Moles/Liter \\
\hline $\mathrm{Al}$ & 14682 & 0.544 & 10000 & 0.371 \\
\hline $\mathrm{B}$ & 44 & 0.0041 & 30 & 0.00277 \\
\hline $\mathrm{Cd}$ & 73 & 0.00065 & 50 & 0.00044 \\
\hline $\mathrm{Ca}$ & 587 & 0.0146 & 400 & 0.00998 \\
\hline $\mathrm{CO}_{3}{ }^{-2}$ & 65650 & 1.09 & 44714 & 0.745 \\
\hline $\mathrm{Co}$ & 4 & 0.000068 & 3 & 0.000046 \\
\hline
\end{tabular}


WSRC-TR-2002-00040, REV. 0, SRT-RPP-2002-00012. REV. 0

\begin{tabular}{|c|c|c|c|c|}
\hline & \multicolumn{2}{|c|}{ Undiluted } & \multicolumn{2}{c|}{ Diluted to 6.5 M Na } \\
\hline Component & mg/Liter & Moles/Liter & mg/Liter & Moles/Liter \\
\hline $\mathrm{Cr}$ & 301 & 0.0058 & 205 & 0.0039 \\
\hline $\mathrm{Cs}$ & 19 & 0.00014 & 13 & 0.000097 \\
\hline $\mathrm{Cu}$ & 29 & 0.00046 & 20 & 0.00031 \\
\hline $\mathrm{OH}$ & 8075 & 0.475 & 5500 & 0.323 \\
\hline $\mathrm{Fe}$ & 50 & 0.000895 & 34 & 0.00061 \\
\hline $\mathrm{K}$ & 2378 & 0.0608 & 1620 & 0.0414 \\
\hline $\mathrm{La}$ & 19 & 0.00014 & 13 & 0.000093 \\
\hline $\mathrm{Mn}$ & 35 & 0.00064 & 24 & 0.00043 \\
\hline $\mathrm{Mo}$ & 54 & 0.00056 & 37 & 0.00038 \\
\hline $\mathrm{Na}$ & 219400 & 9.543 & 149430 & 6.5 \\
\hline $\mathrm{Nd}$ & 38 & 0.00026 & 26 & 0.00018 \\
\hline $\mathrm{NH} \mathrm{H}_{3}$ & 176 & 0.0098 & 120 & 0.0066 \\
\hline $\mathrm{Ni}$ & 499 & 0.0085 & 340 & 0.0058 \\
\hline $\mathrm{Pb}$ & 222 & 0.001 & 151 & 0.00073 \\
\hline $\mathrm{Rb}$ & 10 & 0.00012 & 7 & 0.00008 \\
\hline $\mathrm{Si}$ & 12 & 0.00043 & 8 & 0.00029 \\
\hline $\mathrm{Sr}$ & 3 & 0.000034 & 2 & 0.000023 \\
\hline $\mathrm{W}$ & 201 & 0.0011 & 137 & 0.00075 \\
\hline $\mathrm{Zn}$ & 6 & 0.000092 & 4 & 0.000063 \\
\hline $\mathrm{Zr}$ & 16 & 0.00018 & 11 & 0.00012 \\
\hline $\mathrm{Chloride}$ & 5726 & 0.16 & 3900 & 0.11 \\
\hline Fluoride & 2055 & 0.108 & 1400 & 0.0737 \\
\hline $\mathrm{Nitrate}$ & 234910 & 3.79 & 160000 & 2.58 \\
\hline $\mathrm{Nitrite}$ & 92500 & 2.01 & 63000 & 1.37 \\
\hline $\mathrm{Phosphate}$ & 6607 & 0.0696 & 4500 & 0.0474 \\
\hline $\mathrm{Sulfate}$ & 15108 & 0.157 & 10290 & 0.107 \\
\hline $\mathrm{TIC}$ & 13140 & 1.09 & 8950 & 0.745 \\
\hline $\mathrm{TOC}$ & 27194 & 2.26 & 18522 & 1.54 \\
\hline & & & & \\
\hline
\end{tabular}

The basis for the organic components is listed in Table 4 including the sodium gluconate value whose derivation is explained below.

Table 4 Organic Basis for the AN-102 Supernate Simulant

\begin{tabular}{|c|c|c|c|c|}
\hline & \multicolumn{2}{|c|}{ Undiluted } & \multicolumn{2}{c|}{ Diluted to 6.5 M Na } \\
\hline Component & mg/Liter & Moles/Liter & mg/Liter & Moles/Liter \\
\hline $\begin{array}{c}\text { Ethylenediaminetetraacetate (EDTA } \\
\text { anion) }\end{array}$ & 3318 & 0.0115 & 2260 & 0.0078 \\
\hline $\begin{array}{c}\text { n-(2- } \\
\begin{array}{c}\text { Hydroxyethyl)ethylenediaminetriacetate } \\
\text { (HEDTA anion) }\end{array}\end{array}$ & 440 & 0.0016 & 300 & 0.00109 \\
\hline Oxalate & 554 & 0.0063 & 377 & 0.0043 \\
\hline Glycolate & 12524 & 0.167 & 8530 & 0.114 \\
\hline Citrate & 5580 & 0.0295 & 3800 & 0.0201 \\
\hline Formate & 10070 & 0.224 & 6860 & 0.152 \\
\hline Acetate & 925 & 0.016 & 630 & 0.0107 \\
\hline
\end{tabular}


WSRC-TR-2002-00040, REV. 0, SRT-RPP-2002-00012. REV. 0

\begin{tabular}{|c|c|c|c|c|}
\hline & \multicolumn{2}{|c|}{ Undiluted } & \multicolumn{2}{c|}{ Diluted to 6.5 M Na } \\
\hline Component & mg/Liter & Moles/Liter & mg/Liter & Moles/Liter \\
\hline Nitrilotriacetate (NTA anion) & 310 & 0.00165 & 211 & 0.00112 \\
\hline Succinate & 43 & 0.00037 & 29 & 0.00025 \\
\hline Sodium Gluconate & 1970 & 0.009 & 1342 & 0.0062 \\
\hline Iminodiacetate (IDA anion) & 5366 & 0.0409 & 3655 & 0.0279 \\
\hline Glutaric Acid & 78 & 0.0006 & 53 & 0.00041 \\
\hline Adipic Acid & 294 & 0.002 & 200 & 0.0014 \\
\hline Suberic Acid & 2167 & 0.0126 & 1476 & 0.0086 \\
\hline Azelaic Acid & 1233 & 0.0066 & 840 & 0.0045 \\
\hline
\end{tabular}

Ethylenediaminetetraacetate (EDTA) concentration is the sum of EDTA and of ethylenediaminetriacetate (ED3A) concentrations.

The final four organic acids were added to the simulant in order to produce a solution with some tendency to foam as observed with the actual AN-102 supernate. The concentrations the final four organic acids were based upon measurements of these compounds in tank AN107 waste because quantitative analysis of these in a sample from tank AN-102 was not available when this report was issued. ${ }^{10,11}$ The concentrations for the rest of the organic components other than sodium gluconate were derived from the information in Table 1 and Table 2.

The basis for a concentration of sodium gluconate for the AN-102 simulant was determined by examining the transition metal solubility as a function of sodium gluconate concentration with all of the other complexing agents held constant. Test solutions were prepared that contained all of the measured waste components but with varying levels of sodium gluconate. After mixing for a minimum of 24 hours, the solutions were filtered through a 0.2-micron nylon filter and the filtrate submitted for analysis by inductively coupled plasma emission spectrophotometry (ICP-ES). This analysis technique is similar to photometric titrations where the absorbance or emission intensity is a linear function of the concentration of a light absorbing or emitting species. In this case, the metal ion is insoluble unless complexed. Therefore, if the solutions are filtered after adding the varying amounts of gluconate ion, then the measured increase in the soluble metal concentration will be directly related to the gluconate concentration. The expected result was that the concentration of soluble iron and other metals would be a linear function of the sodium gluconate concentration. A review of the data on the transition metals revealed that all of the soluble metal concentrations measured varied directly with the sodium gluconate concentration. Figures 1 through 5 show the linear relationship between sodium gluconate and several soluble metal species. 
WSRC-TR-2002-00040, REV. 0,

SRT-RPP-2002-00012. REV. 0

\section{Figure 1 Soluble Lanthanum versus Sodium Gluconate}

Soluble $\mathrm{La}^{+3}$ as a Function of $\mathrm{Na}$ Gluconate

in AN-102 Simulant at $9.543 \mathrm{M} \mathrm{Na}^{+}$

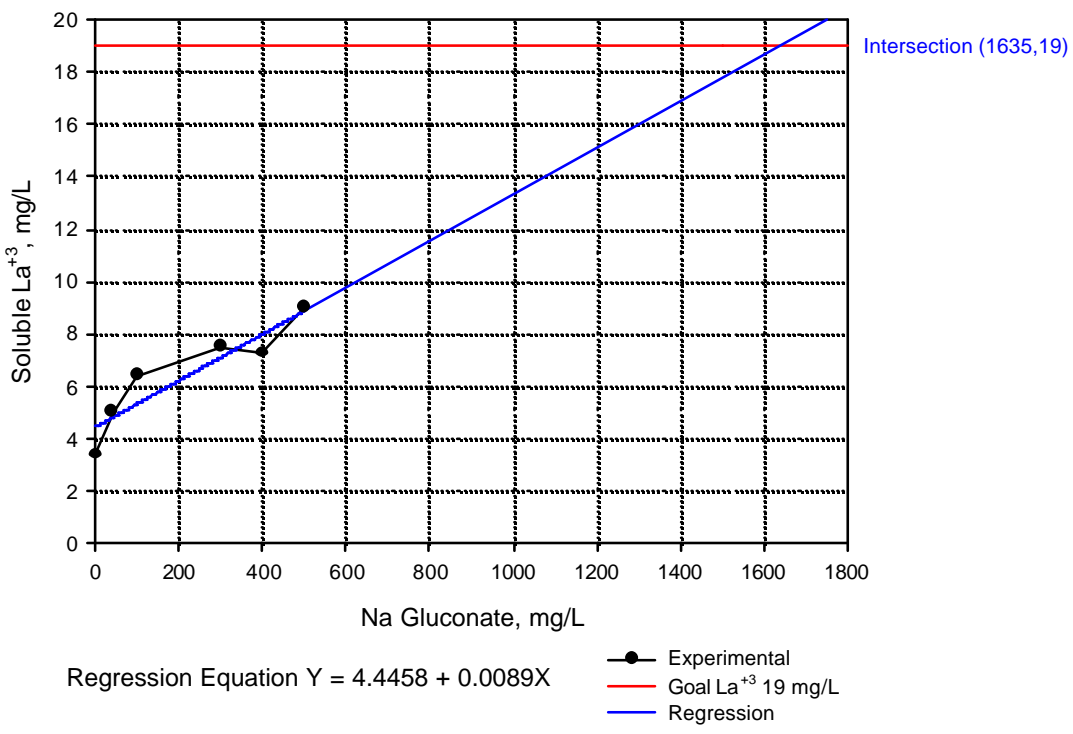

\section{Figure 2 Soluble Iron versus Sodium Gluconate}

Soluble $\mathrm{Fe}^{+3}$ as a Function of $\mathrm{Na}$ Gluconate in AN-102 Simulant at $9.543 \mathrm{M} \mathrm{Na}^{+}$

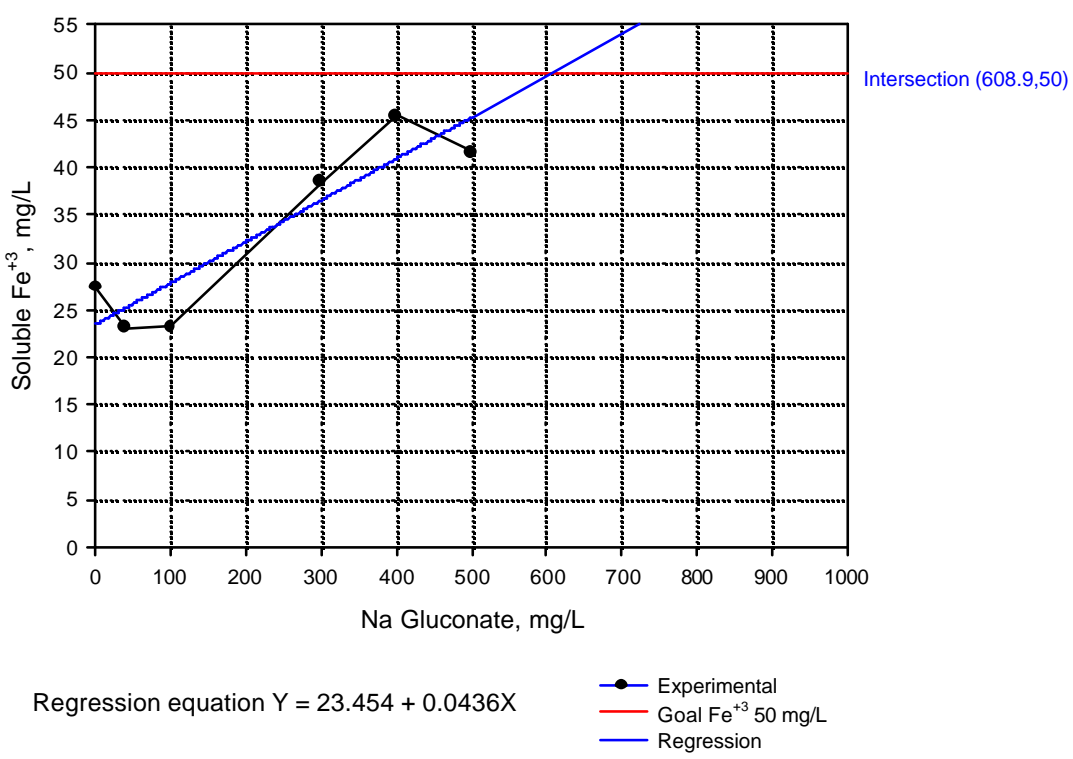


WSRC-TR-2002-00040, REV. 0,

SRT-RPP-2002-00012. REV. 0

\section{Figure 3 Soluble Neodymium versus Sodium Gluconate}

Soluble $\mathrm{Nd}^{+3}$ as a Function of $\mathrm{Na}$ Gluconate in $\mathrm{AN}-102$ Simulant at $9.543 \mathrm{M} \mathrm{Na}^{+}$

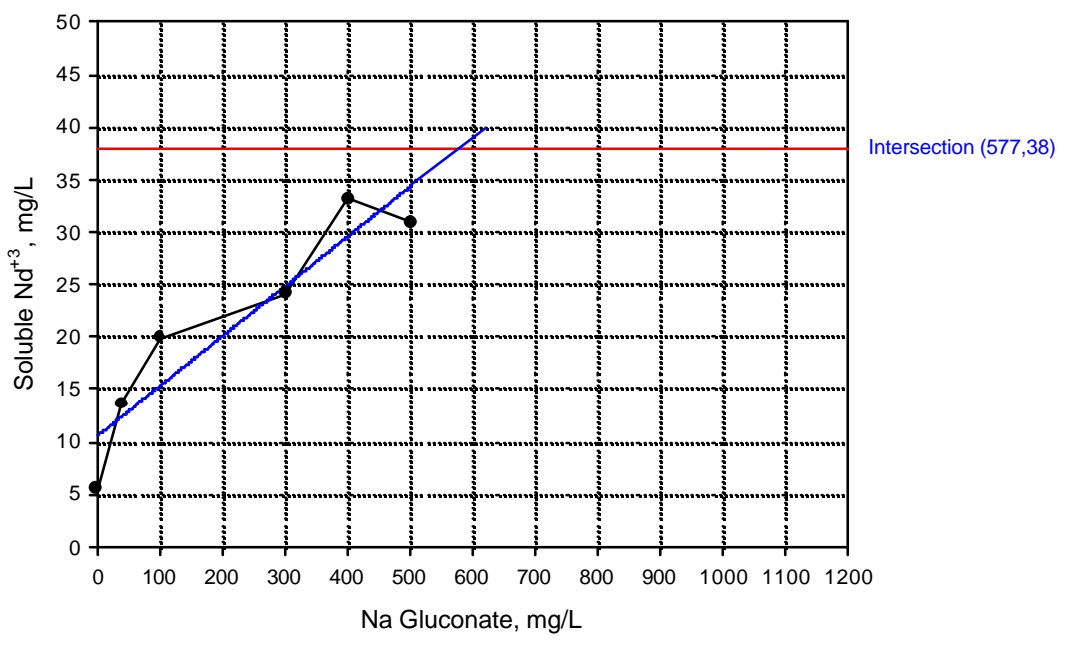

$$
\begin{aligned}
& \text { Regression Equation } Y=10.5714+0.0475 X \quad \longrightarrow \text { Experimental } \\
& \text { - Regression }
\end{aligned}
$$

\section{Figure 4 Soluble Lead versus Sodium Gluconate}

Soluble $\mathrm{Pb}^{+2}$ as a Function of $\mathrm{Na}$ Gluconate in AN-102 Simulant at $9.543 \mathrm{M} \mathrm{Na}^{+}$

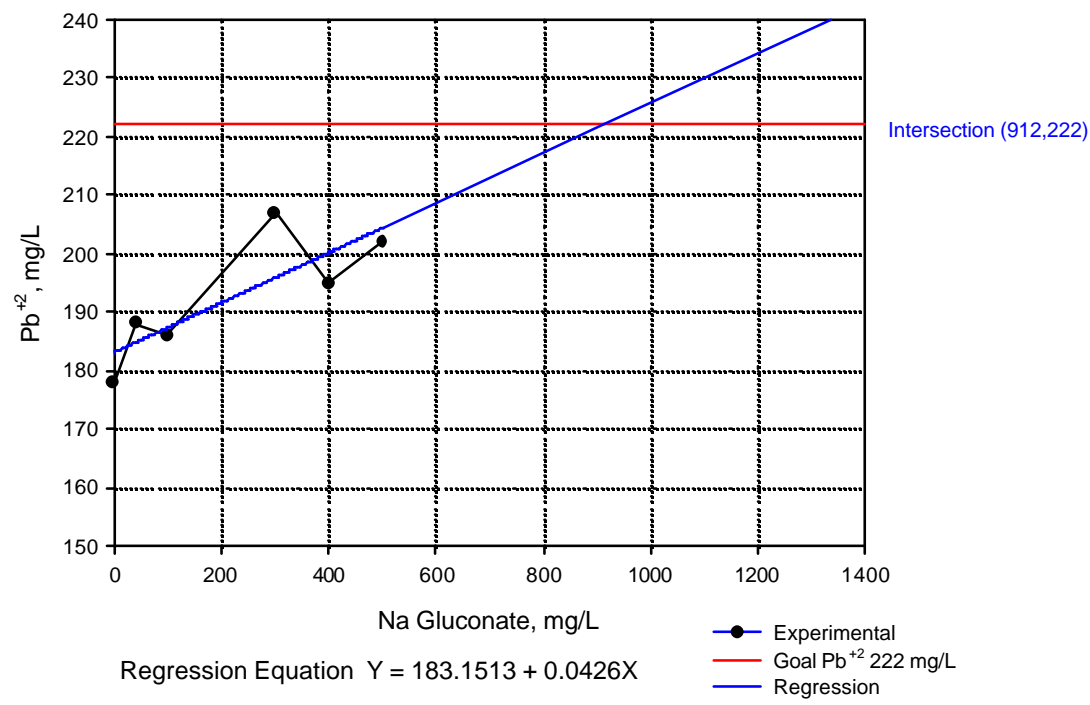




\section{Figure 5 Soluble Manganese versus Sodium Gluconate}

Soluble $\mathrm{Mn}^{+2}$ as a Function of $\mathrm{Na}$ Gluconate

in $\mathrm{AN}-102$ Simulant at $9.543 \mathrm{M} \mathrm{Na}^{+}$

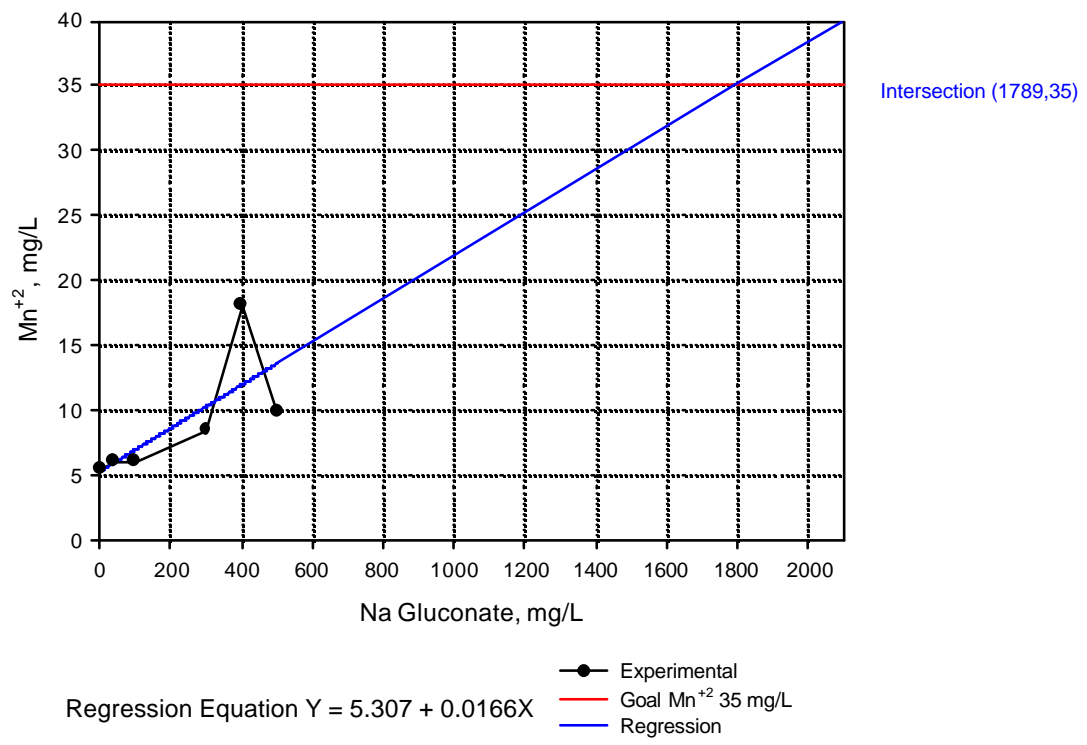

Each set of data was fitted to a straight line as shown on each figure in order to determine the intersection with the target concentration for that metal. The intersection represents the minimum amount of sodium gluconate necessary to achieve the specific metals soluble concentration observed in the actual waste analyses. Table 5 lists the results obtained for the metals in Figures 1 through 5 and for $\mathrm{Ca}$.

Table 5 Calculated Sodium Gluconate Requirement for AN-102 Simulant at 9.5 Molar Na

\begin{tabular}{|c|c|}
\hline Metal & $\begin{array}{c}\text { Required Na Gluconate } \\
\text { Concentration, } \boldsymbol{m g} / \boldsymbol{L}\end{array}$ \\
\hline $\mathrm{Nd}$ & 577 \\
\hline $\mathrm{Fe}$ & 609 \\
\hline $\mathrm{Pb}$ & 912 \\
\hline $\mathrm{La}$ & 1635 \\
\hline $\mathrm{Mn}$ & 1789 \\
\hline $\mathrm{Ca}$ & 2692 \\
\hline
\end{tabular}

A target concentration of sodium gluconate of $1970 \mathrm{mg} / \mathrm{L}$ was chosen as a basis for the undiluted simulant based upon the information shown in Table 5. This was derived from the amount required for manganese plus 10 percent to allow for some analytical variability. The 
value based upon calcium was not used because it was expected that EDTA would complex the calcium when the other metals are sequestered by the gluconate ion.

The first step in converting the analytical values to compounds is to check the balance between negative and positively charged ions. The balance is calculated by multiplying the concentration of an ion in moles/Liter by the charge of the ion and then summing the negative and positive concentrations as shown in Table 6.

Table 6 Charge Balancing Calculations

\begin{tabular}{|c|c|c|c|c|c|c|c|}
\hline \multicolumn{4}{|c|}{ Cations } & \multicolumn{4}{|c|}{ Anions } \\
\hline Species & Charge & Moles/Liter & $\begin{array}{c}\text { Charge, } \\
\text { moles/Liter }\end{array}$ & Species & Charge & Moles/Liter & $\begin{array}{c}\text { Charge, } \\
\text { moles/Liter }\end{array}$ \\
\hline Ammonium & 1 & $9.76 \mathrm{E}-03$ & $9.76 \mathrm{E}-03$ & Acetate & -1 & $1.57 \mathrm{E}-02$ & $-1.57 \mathrm{E}-02$ \\
\hline Barium & 2 & $0.00 \mathrm{E}+00$ & $0.00 \mathrm{E}+00$ & Aluminum & -1 & 5.44E-01 & $-5.44 \mathrm{E}-01$ \\
\hline Cadmium & 2 & $6.49 \mathrm{E}-04$ & $1.30 \mathrm{E}-03$ & Boron & -3 & $4.07 \mathrm{E}-03$ & $-1.22 \mathrm{E}-02$ \\
\hline Calcium & 2 & $1.46 \mathrm{E}-02$ & $2.93 \mathrm{E}-02$ & Carbonate & -2 & $1.09 \mathrm{E}+00$ & $-2.19 \mathrm{E}+00$ \\
\hline Cerium & 3 & $0.00 \mathrm{E}+00$ & $0.00 \mathrm{E}+00$ & Chloride & -1 & $1.62 \mathrm{E}-01$ & $-1.62 \mathrm{E}-01$ \\
\hline Cesium & 1 & $1.43 \mathrm{E}-04$ & $1.43 \mathrm{E}-04$ & Chromium & -2 & $5.79 \mathrm{E}-03$ & $-1.16 \mathrm{E}-02$ \\
\hline Cobalt & 2 & $6.79 \mathrm{E}-05$ & $1.36 \mathrm{E}-04$ & $\begin{array}{c}\text { Ethylenediaminet } \\
\text { etraacetate }\end{array}$ & -4 & $1.15 \mathrm{E}-02$ & $-4.61 \mathrm{E}-02$ \\
\hline Copper & 2 & $4.56 \mathrm{E}-04$ & $9.13 \mathrm{E}-04$ & Fluoride & -1 & $1.08 \mathrm{E}-01$ & $-1.08 \mathrm{E}-01$ \\
\hline Iron & 3 & $8.95 \mathrm{E}-04$ & $2.69 \mathrm{E}-03$ & Formate & -1 & $2.24 \mathrm{E}-01$ & $-2.24 \mathrm{E}-01$ \\
\hline Lanthanum & 3 & $1.37 \mathrm{E}-04$ & $4.10 \mathrm{E}-04$ & Glycolate & -1 & $1.67 \mathrm{E}-01$ & $-1.67 \mathrm{E}-01$ \\
\hline Lead & 2 & $1.07 \mathrm{E}-03$ & $2.14 \mathrm{E}-03$ & Hydroxide & -1 & $4.75 \mathrm{E}-01$ & $-4.75 \mathrm{E}-01$ \\
\hline Magnesium & 1 & $0.00 \mathrm{E}+00$ & $0.00 \mathrm{E}+00$ & Molybdenum & -2 & $5.63 \mathrm{E}-04$ & $-1.13 \mathrm{E}-03$ \\
\hline Manganese & 2 & $6.37 \mathrm{E}-04$ & $1.27 \mathrm{E}-03$ & $\begin{array}{c}\mathrm{n}- \\
\text { Hydroxyethylene } \\
\text { diaminetriacetate }\end{array}$ & -3 & $1.60 \mathrm{E}-03$ & $-4.80 \mathrm{E}-03$ \\
\hline Neodymium & 3 & $2.63 \mathrm{E}-04$ & $7.90 \mathrm{E}-04$ & Nitrate & -1 & $3.79 \mathrm{E}+00$ & $-3.79 \mathrm{E}+00$ \\
\hline Nickel & 2 & $8.50 \mathrm{E}-03$ & $1.70 \mathrm{E}-02$ & Nitrite & -1 & $2.01 \mathrm{E}+00$ & $-2.01 \mathrm{E}+00$ \\
\hline Potassium & 1 & $6.08 \mathrm{E}-02$ & $6.08 \mathrm{E}-02$ & Oxalate & -2 & $6.29 \mathrm{E}-03$ & $-1.26 \mathrm{E}-02$ \\
\hline Rubidium & 1 & $1.17 \mathrm{E}-04$ & $1.17 \mathrm{E}-04$ & Phosphate & -3 & $6.96 \mathrm{E}-02$ & $-2.09 \mathrm{E}-01$ \\
\hline Sodium & 1 & $9.54 \mathrm{E}+00$ & $9.54 \mathrm{E}+00$ & Silicon & -2 & $4.27 \mathrm{E}-04$ & $-8.55 \mathrm{E}-04$ \\
\hline Strontium & 2 & $3.42 \mathrm{E}-05$ & $6.85 \mathrm{E}-05$ & Sulfate & -2 & $1.57 \mathrm{E}-01$ & $-3.15 \mathrm{E}-01$ \\
\hline Zirconium & 4 & $1.75 \mathrm{E}-04$ & 7.02E-04 & Tungsten & -2 & $1.09 \mathrm{E}-03$ & $-2.19 \mathrm{E}-03$ \\
\hline $\begin{array}{c}\text { Sodium } \\
\text { Gluconate }\end{array}$ & 1 & $9.03 \mathrm{E}-03$ & $9.03 \mathrm{E}-03$ & Zinc & -2 & $9.18 \mathrm{E}-05$ & $-1.84 \mathrm{E}-04$ \\
\hline & & & & Nitrilotriacetate & -3 & $1.65 \mathrm{E}-03$ & $-4.94 \mathrm{E}-03$ \\
\hline & & & & Citric Acid & -3 & $2.95 \mathrm{E}-02$ & $-8.85 \mathrm{E}-02$ \\
\hline & & & & Iminodiacetate & -2 & $4.09 \mathrm{E}-02$ & $-8.19 \mathrm{E}-02$ \\
\hline & & & & Succinic Acid & -2 & $3.70 \mathrm{E}-04$ & $-7.41 \mathrm{E}-04$ \\
\hline & & & & Glutaric Acid & -2 & $6.00 \mathrm{E}-04$ & $-1.20 \mathrm{E}-03$ \\
\hline & & & & Adipic Acid & -2 & $2.04 \mathrm{E}-03$ & $-4.08 \mathrm{E}-03$ \\
\hline & & & & Azelaic Acid & -2 & $6.62 \mathrm{E}-03$ & $-1.32 \mathrm{E}-02$ \\
\hline & & & & Suberic Acid & -2 & $1.26 \mathrm{E}-02$ & $-2.52 \mathrm{E}-02$ \\
\hline & & & & $\begin{array}{c}\text { Sodium } \\
\text { Gluconate }\end{array}$ & -1 & $9.03 \mathrm{E}-03$ & $-9.03 E-03$ \\
\hline \multicolumn{2}{|c|}{ Total Plus Charge } & & 9.68 & \multicolumn{2}{|c|}{ Total Minus Charge } & & -10.53 \\
\hline
\end{tabular}


The charge balance based upon the information in Table 6 was 0.846 moles more anions than cations (balance is $92 \%$ ). Reducing the hydroxide concentration to achieve charge balance was not possible or desirable without disturbing the aluminum solubility. Charge balancing by adjusting the carbonate level was not recommended because the carbonate concentration is crucial to the Sr/TRU precipitation process. Another option for achieving the charge balance was to adjust either the nitrate or nitrite concentrations. However, the relative concentrations of nitrate to nitrite were assumed to control the redox of the supernate. Therefore, the concentrations of nitrate and nitrite anions for an undiluted AN-102 supernate were proportionately decreased by 0.846 moles/Liter $\left(\mathrm{NO}_{3}{ }^{-}\right.$by 0.553 and $\mathrm{NO}_{2}{ }^{-}$by 0.293 moles/Liter). Table 7 gives the concentrations of nitrate and nitrite anions after revising to obtain a charge-balanced composition.

Table 7 Revised Nitrate and Nitrite Concentrations from Charge Balancing

\begin{tabular}{|c|c|c|c|c|}
\hline & \multicolumn{2}{|c|}{ Undiluted } & \multicolumn{2}{c|}{ Diluted to 6.5 M Na } \\
\hline Component & mg/Liter & Moles/Liter & mg/Liter & Moles/Liter \\
\hline Nitrate & 200640 & 3.24 & 136660 & 2.20 \\
\hline Nitrite & 79006 & 1.72 & 53810 & 1.17 \\
\hline
\end{tabular}

Based upon a volumetric preparation of the diluted 6.5 molar simulant, the density of the AN-102 simulant at 6.53 molar Na was 1.303 grams $/ \mathrm{mL}$ at $298 \mathrm{~K}$. The density for the undiluted AN-102 simulant (9.5 Molar Na) was 1.434 grams/mL at $298 \mathrm{~K}$.

Table 8 and Table 9 list the formulation of the 6.5 molar and 9.5 molar sodium simulant. A variation on this formulation has also been used which uses the trisodium salt of HEDTA and, therefore, uses slightly less sodium hydroxide.

The organic compounds in the simulant account for $58 \%$ of the measured TOC (total organic carbon) in the actual waste. Matching the measured TOC was not attempted because complete identification and quantitation of all organic compounds would be necessary to match the TOC. If the known or currently measured organic species were increased to match the TOC, then additional charge balance problems would arise because it is assumed that the remaining organic species are oxidized portions of the complexing agents (typically organic acids). These remaining organic species are produced by reactions between the complexing agents and the reactive intermediates $\left(\mathrm{OH}^{-}\right.$and $\left.\mathrm{O}^{-}\right)$produced by the radiolysis of water in the presence of hydroxide ion.

Table 8 AN-102 Supernate Simulant Formulation at 6.5 Molar Na

\begin{tabular}{|c|c|c|}
\hline Compounds & Formula & Grams/Liter \\
\hline Aluminum Nitrate & $\mathrm{Al}\left(\mathrm{NO}_{3}\right)_{3} \bullet 9 \mathrm{H}_{2} \mathrm{O}$ & 139.03 \\
\hline Boric Acid & $\mathrm{H}_{3} \mathrm{BO}_{3}$ & 0.17 \\
\hline Cadmium Nitrate & $\mathrm{Cd}\left(\mathrm{NO}_{3}\right)_{2} \bullet 4 \mathrm{H}_{2} \mathrm{O}$ & 0.14 \\
\hline Calcium Nitrate & $\mathrm{Ca}\left(\mathrm{NO}_{3}\right)_{2} \bullet 4 \mathrm{H}_{2} \mathrm{O}$ & 2.36 \\
\hline Cesium Nitrate & $\mathrm{CsNO}_{3}$ & 0.019 \\
\hline Cobalt Nitrate & $\mathrm{Co}\left(\mathrm{NO}_{3}\right)_{2} \bullet 6 \mathrm{H}_{2} \mathrm{O}$ & 0.013 \\
\hline Copper Nitrate & $\mathrm{Cu}\left(\mathrm{NO}_{3}\right)_{2} \bullet 2.5 \mathrm{H}_{2} \mathrm{O}$ & 0.07 \\
\hline
\end{tabular}


WSRC-TR-2002-00040, REV. 0, SRT-RPP-2002-00012. REV. 0

\begin{tabular}{|c|c|c|}
\hline Compounds & Formula & Grams/Liter \\
\hline Disodium EDTA & $\mathrm{C}_{10} \mathrm{H}_{14} \mathrm{~N}_{2} \mathrm{Na}_{2} \mathrm{O}_{8} \bullet 2 \mathrm{H}_{2} \mathrm{O}$ & 2.92 \\
\hline Ferric Nitrate & $\mathrm{Fe}\left(\mathrm{NO}_{3}\right)_{3} \bullet 9 \mathrm{H}_{2} \mathrm{O}$ & 0.25 \\
\hline HEDTA & $\mathrm{C}_{10} \mathrm{H}_{18} \mathrm{~N}_{2} \mathrm{O}_{7}$ & 0.30 \\
\hline Lanthanum Nitrate & $\mathrm{La}\left(\mathrm{NO}_{3}\right)_{3} \bullet 6 \mathrm{H}_{2} \mathrm{O}$ & 0.04 \\
\hline Lead nitrate & $\mathrm{Pb}\left(\mathrm{NO}_{3}\right)_{2}$ & 0.24 \\
\hline Manganous Chloride & $\mathrm{MnCl}_{2} \bullet 4 \mathrm{H}_{2} \mathrm{O}$ & 0.09 \\
\hline Neodymium Nitrate & $\mathrm{Nd}\left(\mathrm{NO}_{3}\right)_{3} \bullet 6 \mathrm{H}_{2} \mathrm{O}$ & 0.08 \\
\hline Nickel Nitrate & $\mathrm{Ni}\left(\mathrm{NO}_{3}\right)_{2} \bullet 6 \mathrm{H}_{2} \mathrm{O}$ & 1.68 \\
\hline Potassium Nitrate & $\mathrm{KNO}_{3}$ & 4.11 \\
\hline Rubidium Nitrate & $\mathrm{RbNO}_{3}$ & 0.01 \\
\hline Strontium Nitrate & $\mathrm{Sr}\left(\mathrm{NO}_{3}\right)_{2}$ & 0.005 \\
\hline Zinc Nitrate & $\mathrm{Zn}\left(\mathrm{NO}_{3}\right)_{2} \bullet 6 \mathrm{H}_{2} \mathrm{O}$ & 0.02 \\
\hline Zirconyl Nitrate & $\mathrm{ZrO}\left(\mathrm{NO}_{3}\right)_{2^{\bullet}} \times \mathrm{H}_{2} \mathrm{O}, \mathrm{x} \sim 1$ & 0.03 \\
\hline Sodium Glycolate & $\mathrm{HOCH}_{2} \mathrm{COONa}$ & 11.14 \\
\hline Sodium Gluconate & $\mathrm{C}_{6} \mathrm{H}_{11} \mathrm{O}_{7} \mathrm{Na}$ & 1.34 \\
\hline Citric Acid & $\mathrm{C}_{6} \mathrm{H}_{8} \mathrm{O}_{7} \bullet \mathrm{H}_{2} \mathrm{O}$ & 4.22 \\
\hline Nitrilotriacetic Acid & $\mathrm{C}_{6} \mathrm{H}_{9} \mathrm{NO}_{6}$ & 0.21 \\
\hline Iminodiacetic Acid & $\mathrm{C}_{4} \mathrm{H}_{7} \mathrm{NO}_{4}$ & 3.71 \\
\hline Succinic Acid & $\mathrm{C}_{4} \mathrm{H}_{6} \mathrm{O}_{4}$ & 0.03 \\
\hline Glutaric Acid & $\mathrm{C}_{5} \mathrm{H}_{8} \mathrm{O}_{4}$ & 0.05 \\
\hline Adipic Acid & $\mathrm{C}_{6} \mathrm{H}_{10} \mathrm{O}_{4}$ & 0.20 \\
\hline Suberic Acid & $\mathrm{C}_{8} \mathrm{H}_{14} \mathrm{O}_{4}$ & 1.49 \\
\hline Azelaic Acid & $\mathrm{C}_{9} \mathrm{H}_{16} \mathrm{O}_{4}$ & 0.85 \\
\hline Sodium Chloride & $\mathrm{NaCl}$ & 6.38 \\
\hline Sodium Fluoride & $\mathrm{NaF}$ & 3.09 \\
\hline Sodium Chromate & $\mathrm{Na}_{2} \mathrm{CrO}_{4}$ & 0.64 \\
\hline Sodium Sulfate & $\mathrm{Na}_{2} \mathrm{SO}_{4}$ & 15.22 \\
\hline Ammonium Acetate & $\mathrm{NH}_{4} \mathrm{CH}_{3} \mathrm{COO}$ & 0.51 \\
\hline Potassium Molybdate & $\mathrm{K}_{2} \mathrm{MoO}_{4}$ & 0.09 \\
\hline Sodium Hydroxide & $\mathrm{NaOH}$ & 79.31 \\
\hline Sodium Oxalate & $\mathrm{Na}_{2} \mathrm{C}_{2} \mathrm{O}_{4}$ & 0.57 \\
\hline Sodium Acetate & $\mathrm{NaCH}_{3} \mathrm{COO} \cdot 3 \mathrm{H}_{2} \mathrm{O}$ & 0.55 \\
\hline Sodium Formate & $\mathrm{NaHCOO}$ & 10.36 \\
\hline Sodium Phosphate & $\mathrm{Na}_{3} \mathrm{PO}_{4} \bullet 12 \mathrm{H}_{2} \mathrm{O}$ & 18.01 \\
\hline Sodium Tungstate & $\mathrm{Na}_{2} \mathrm{WO}_{4} \bullet 2 \mathrm{H}_{2} \mathrm{O}$ & 0.25 \\
\hline Sodium Metasilicate & $\mathrm{Na}_{2} \mathrm{SiO}_{3} \bullet 9 \mathrm{H}_{2} \mathrm{O}$ & 0.08 \\
\hline Sodium Carbonate & $\mathrm{Na}_{2} \mathrm{CO}_{3}$ & 78.98 \\
\hline Sodium Nitrate & $\mathrm{NaNO}_{3}$ & 87.85 \\
\hline Sodium Nitrite & $\mathrm{NaNO}_{2}$ & 80.71 \\
\hline Water & $\mathrm{H}_{2} \mathrm{O}$ & 745.58 \\
\hline
\end{tabular}

Table 9 AN-102 Supernate Simulant Formulation at 9.5 Molar Na

\begin{tabular}{|c|c|c|}
\hline Compounds & Formula & Grams/Liter \\
\hline Aluminum Nitrate & $\mathrm{Al}\left(\mathrm{NO}_{3}\right)_{3} \bullet 9 \mathrm{H}_{2} \mathrm{O}$ & 204.12 \\
\hline Boric Acid & $\mathrm{H}_{3} \mathrm{BO}_{3}$ & 0.25 \\
\hline Cadmium Nitrate & $\mathrm{Cd}\left(\mathrm{NO}_{3}\right)_{2} \bullet 4 \mathrm{H}_{2} \mathrm{O}$ & 0.20 \\
\hline Calcium Nitrate & $\mathrm{Ca}\left(\mathrm{NO}_{3}\right)_{2} \bullet 4 \mathrm{H}_{2} \mathrm{O}$ & 3.46 \\
\hline Cesium Nitrate & $\mathrm{CsNO}_{3}$ & 0.028 \\
\hline Cobalt Nitrate & $\mathrm{Co}\left(\mathrm{NO}_{3}\right)_{2} \bullet 6 \mathrm{H}_{2} \mathrm{O}$ & 0.02 \\
\hline Copper Nitrate & $\mathrm{Cu}\left(\mathrm{NO}_{3}\right)_{2} \bullet 2.5 \mathrm{H}_{2} \mathrm{O}$ & 0.11 \\
\hline Disodium EDTA & $\mathrm{C}_{10} \mathrm{H}_{14} \mathrm{~N}_{2} \mathrm{Na}_{2} \mathrm{O}_{8} \bullet 2 \mathrm{H}_{2} \mathrm{O}$ & 4.29 \\
\hline Ferric Nitrate & $\mathrm{Fe}\left(\mathrm{NO}_{3}\right)_{3} \bullet 9 \mathrm{H}_{2} \mathrm{O}$ & 0.36 \\
\hline HEDTA & $\mathrm{C}_{11} \mathrm{H}_{18} \mathrm{~N}_{2} \mathrm{O}_{7}$ & 0.44 \\
\hline Lanthanum Nitrate & $\mathrm{La}\left(\mathrm{NO}_{3}\right)_{3} \bullet 6 \mathrm{H}_{2} \mathrm{O}$ & 0.06 \\
\hline Lead nitrate & $\mathrm{Pb}_{\left(\mathrm{NO}_{3}\right)_{2}}$ & 0.35 \\
\hline
\end{tabular}


WSRC-TR-2002-00040, REV. 0, SRT-RPP-2002-00012. REV. 0

\begin{tabular}{|c|c|c|}
\hline Compounds & Formula & Grams/Liter \\
\hline Manganous Chloride & $\mathrm{MnCl}_{2} \bullet 4 \mathrm{H}_{2} \mathrm{O}$ & 0.13 \\
\hline Neodymium Nitrate & $\mathrm{Nd}\left(\mathrm{NO}_{3}\right)_{3} \bullet 6 \mathrm{H}_{2} \mathrm{O}$ & 0.12 \\
\hline Nickel Nitrate & $\mathrm{Ni}\left(\mathrm{NO}_{3}\right)_{2} \bullet 6 \mathrm{H}_{2} \mathrm{O}$ & 2.47 \\
\hline Potassium Nitrate & $\mathrm{KNO}_{3}$ & 6.03 \\
\hline Rubidium Nitrate & $\mathrm{RbNO}_{3}$ & 0.02 \\
\hline Strontium Nitrate & $\mathrm{Sr}\left(\mathrm{NO}_{3}\right)_{2}$ & 0.007 \\
\hline Zinc Nitrate & $\mathrm{Zn}\left(\mathrm{NO}_{3}\right)_{2} \bullet 6 \mathrm{H}_{2} \mathrm{O}$ & 0.03 \\
\hline Zirconyl Nitrate & $\mathrm{ZrO}\left(\mathrm{NO}_{3}\right)_{2} \bullet \mathrm{xH}_{2} \mathrm{O}, \mathrm{x} \sim 1$ & 0.04 \\
\hline Sodium Glycolate & $\mathrm{HOCH}_{2} \mathrm{COONa}$ & 16.36 \\
\hline Sodium Gluconate & $\mathrm{C}_{6} \mathrm{H}_{11} \mathrm{O}_{7} \mathrm{Na}$ & 1.97 \\
\hline Citric Acid & $\mathrm{C}_{6} \mathrm{H}_{8} \mathrm{O}_{7} \cdot \mathrm{H}_{2} \mathrm{O}$ & 6.20 \\
\hline Nitrilotriacetic Acid & $\mathrm{C}_{6} \mathrm{H}_{9} \mathrm{NO}_{6}$ & 0.31 \\
\hline Iminodiacetic Acid & $\mathrm{C}_{4} \mathrm{H}_{7} \mathrm{NO}_{4}$ & 5.45 \\
\hline Succinic Acid & $\mathrm{C}_{4} \mathrm{H}_{6} \mathrm{O}_{4}$ & 0.04 \\
\hline Glutaric Acid & $\mathrm{C}_{5} \mathrm{H}_{8} \mathrm{O}_{4}$ & 0.08 \\
\hline Adipic Acid & $\mathrm{C}_{6} \mathrm{H}_{10} \mathrm{O}_{4}$ & 0.30 \\
\hline Suberic Acid & $\mathrm{C}_{8} \mathrm{H}_{14} \mathrm{O}_{4}$ & 2.19 \\
\hline Azelaic Acid & $\mathrm{C}_{9} \mathrm{H}_{16} \mathrm{O}_{4}$ & 1.25 \\
\hline Sodium Chloride & $\mathrm{NaCl}$ & 9.36 \\
\hline Sodium Fluoride & $\mathrm{NaF}$ & 4.54 \\
\hline Sodium Chromate & $\mathrm{Na}_{2} \mathrm{CrO}_{4}$ & 0.94 \\
\hline Sodium Sulfate & $\mathrm{Na}_{2} \mathrm{SO}_{4}$ & 22.34 \\
\hline Ammonium Acetate & $\mathrm{NH}_{4} \mathrm{CH}_{3} \mathrm{COO}$ & 0.75 \\
\hline Potassium Molybdate & $\mathrm{K}_{2} \mathrm{MoO}_{4}$ & 0.13 \\
\hline Sodium Hydroxide & $\mathrm{NaOH}$ & 116.44 \\
\hline Sodium Oxalate & $\mathrm{Na}_{2} \mathrm{C}_{2} \mathrm{O}_{4}$ & 0.84 \\
\hline Sodium Acetate & $\mathrm{NaCH}_{3} \mathrm{COO} \cdot 3 \mathrm{H}_{2} \mathrm{O}$ & 0.80 \\
\hline Sodium Formate & $\mathrm{NaHCOO}$ & 15.22 \\
\hline Sodium Phosphate & $\mathrm{Na}_{3} \mathrm{PO}_{4} \bullet 12 \mathrm{H}_{2} \mathrm{O}$ & 26.44 \\
\hline Sodium Tungstate & $\mathrm{Na}_{2} \mathrm{WO}_{4} \cdot 2 \mathrm{H}_{2} \mathrm{O}$ & 0.36 \\
\hline Sodium Metasilicate & $\mathrm{Na}_{2} \mathrm{SiO}_{3} \bullet 9 \mathrm{H}_{2} \mathrm{O}$ & 0.12 \\
\hline Sodium Carbonate & $\mathrm{Na}_{2} \mathrm{CO}_{3}$ & 115.95 \\
\hline Sodium Nitrate & $\mathrm{NaNO}_{3}$ & 128.98 \\
\hline Sodium Nitrite & $\mathrm{NaNO}_{2}$ & 118.50 \\
\hline Water & $\mathrm{H}_{2} \mathrm{O}$ & 615.60 \\
\hline
\end{tabular}

Table 8 and Table 9 do not specify the sequence of addition that was determined to produce an acceptable simulant. The procedure with the correct addition sequence used to produce one liter of the AN-102 supernate simulant at 6.5 molar $\mathrm{Na}$ is listed in Table 10.

Table 10 Procedure for One Liter of AN-102 Supernate Simulant at 6.5 Molar Na

\begin{tabular}{|c|c|c|}
\hline Volume of Feed & $\mathbf{1 0 0 0}$ & mL \\
\hline To the Simulant Preparation Vessel Add & Grams \\
\hline Water & 200 \\
\hline
\end{tabular}

Next add the following while maintaining good mixing

\begin{tabular}{|l|c|c|}
\hline Metal Compounds and Complexants & Formula & Mass Needed, grams \\
\hline Aluminum Nitrate & $\mathrm{Al}\left(\mathrm{NO}_{3}\right)_{3} \bullet 9 \mathrm{H}_{2} \mathrm{O}$ & 139.03 \\
\hline Cadmium Nitrate & $\mathrm{Cd}\left(\mathrm{NO}_{3}\right)_{2} \bullet 4 \mathrm{H}_{2} \mathrm{O}$ & 0.14 \\
\hline Calcium Nitrate & $\mathrm{Ca}\left(\mathrm{NO}_{3}\right)_{2} \bullet 4 \mathrm{H}_{2} \mathrm{O}$ & 2.36 \\
\hline Cesium Nitrate & $\mathrm{CsNO}_{3}$ & 0.019 \\
\hline Copper Nitrate & $\mathrm{Cu}\left(\mathrm{NO}_{3}\right)_{2} \bullet 2.5 \mathrm{H}_{2} \mathrm{O}$ & 0.07 \\
\hline Cobalt Nitrate & $\mathrm{Co}\left(\mathrm{NO}_{3}\right)_{2} \bullet 6 \mathrm{H}_{2} \mathrm{O}$ & 0.013 \\
\hline
\end{tabular}


WSRC-TR-2002-00040, REV. 0, SRT-RPP-2002-00012. REV. 0

\begin{tabular}{|c|c|c|}
\hline Ferric Nitrate & $\mathrm{Fe}\left(\mathrm{NO}_{3}\right)_{3} \bullet 9 \mathrm{H}_{2} \mathrm{O}$ & 0.25 \\
\hline Lanthanum Nitrate & $\mathrm{La}\left(\mathrm{NO}_{3}\right)_{3} \bullet 6 \mathrm{H}_{2} \mathrm{O}$ & 0.04 \\
\hline Lead nitrate & $\mathrm{Pb}\left(\mathrm{NO}_{3}\right)_{2}$ & 0.24 \\
\hline Manganous Chloride & $\mathrm{MnCl}_{2} \bullet 4 \mathrm{H}_{2} \mathrm{O}$ & 0.09 \\
\hline Neodymium Nitrate & $\mathrm{Nd}\left(\mathrm{NO}_{3}\right)_{3} \bullet 6 \mathrm{H}_{2} \mathrm{O}$ & 0.08 \\
\hline Nickel Nitrate & $\mathrm{Ni}\left(\mathrm{NO}_{3}\right)_{2} \bullet 6 \mathrm{H}_{2} \mathrm{O}$ & 1.68 \\
\hline Potassium Nitrate & $\mathrm{KNO}_{3}$ & 4.11 \\
\hline Rubidium Nitrate & $\mathrm{RbNO}_{3}$ & 0.01 \\
\hline Strontium Nitrate & $\mathrm{Sr}\left(\mathrm{NO}_{3}\right)_{2}$ & 0.005 \\
\hline Zinc Nitrate & $\mathrm{Zn}\left(\mathrm{NO}_{3}\right)_{2} \bullet 6 \mathrm{H}_{2} \mathrm{O}$ & 0.02 \\
\hline Zirconyl Nitrate & $\mathrm{ZrO}\left(\mathrm{NO}_{3}\right)_{2} \bullet \mathrm{xH}_{2} \mathrm{O}, \mathrm{x} \sim 1$ & 0.03 \\
\hline Disodium Ethylenediaminetetraacetate & $\mathrm{C}_{10} \mathrm{H}_{14} \mathrm{~N}_{2} \mathrm{Na}_{2} \mathrm{O}_{8} \bullet 2 \mathrm{H}_{2} \mathrm{O}$ & 2.92 \\
\hline $\begin{array}{l}\text { n-(2-Hydroxyethyl)ethylenediaminetriacetic } \\
\text { acid }\end{array}$ & $\mathrm{C}_{10} \mathrm{H}_{18} \mathrm{~N}_{2} \mathrm{O}_{7}$ & 0.30 \\
\hline Sodium Gluconate & $\mathrm{C}_{6} \mathrm{H}_{11} \mathrm{O}_{7} \mathrm{Na}$ & 1.34 \\
\hline Citric Acid & $\mathrm{C}_{6} \mathrm{H}_{8} \mathrm{O}_{7} \bullet \mathrm{H}_{2} \mathrm{O}$ & 4.22 \\
\hline Nitrilotriacetic Acid & $\mathrm{C}_{6} \mathrm{H}_{9} \mathrm{NO}_{6}$ & 0.21 \\
\hline Iminodiacetic Acid & $\mathrm{C}_{4} \mathrm{H}_{7} \mathrm{NO}_{4}$ & 3.71 \\
\hline Succinic Acid & $\mathrm{C}_{4} \mathrm{H}_{6} \mathrm{O}_{4}$ & 0.03 \\
\hline Glutaric Acid & $\mathrm{C}_{5} \mathrm{H}_{8} \mathrm{O}_{4}$ & 0.05 \\
\hline Adipic Acid & $\mathrm{C}_{6} \mathrm{H}_{10} \mathrm{O}_{4}$ & 0.20 \\
\hline Suberic Acid & $\mathrm{C}_{8} \mathrm{H}_{14} \mathrm{O}_{4}$ & 1.49 \\
\hline Azelaic Acid & $\mathrm{C}_{9} \mathrm{H}_{16} \mathrm{O}_{4}$ & 0.85 \\
\hline Boric acid & $\mathrm{H}_{3} \mathrm{BO}_{3}$ & 0.17 \\
\hline Ammonium Acetate & $\mathrm{NH}_{4} \mathrm{CH}_{3} \mathrm{COO}$ & 0.51 \\
\hline Sodium Chloride & $\mathrm{NaCl}$ & 6.38 \\
\hline Sodium Fluoride & $\mathrm{NaF}$ & 3.09 \\
\hline Sodium Sulfate & $\mathrm{Na}_{2} \mathrm{SO}_{4}$ & 15.22 \\
\hline Potassium Molybdate & $\mathrm{K}_{2} \mathrm{MoO}_{4}$ & 0.09 \\
\hline $\begin{array}{l}\text { Mix thoroughly. Then add the following } \\
\text { while mixing. }\end{array}$ & Formula & Mass Needed, grams \\
\hline Sodium Hydroxide & $\mathrm{NaOH}$ & 79.31 \\
\hline Sodium Phosphate & $\mathrm{Na}_{3} \mathrm{PO}_{4} \bullet 12 \mathrm{H}_{2} \mathrm{O}$ & 18.01 \\
\hline Sodium Tungstate & $\mathrm{Na}_{2} \mathrm{WO}_{4} \bullet 2 \mathrm{H}_{2} \mathrm{O}$ & 0.25 \\
\hline Sodium Metasilicate & $\mathrm{Na}_{2} \mathrm{SiO}_{3} \bullet 9 \mathrm{H}_{2} \mathrm{O}$ & 0.08 \\
\hline Sodium Glycolate & $\mathrm{HOCH}_{2} \mathrm{COONa}$ & 11.14 \\
\hline Sodium formate & $\mathrm{NaHCOO}$ & 10.36 \\
\hline Sodium Acetate & $\mathrm{NaCH}_{3} \mathrm{COO} \bullet 3 \mathrm{H}_{2} \mathrm{O}$ & 0.55 \\
\hline Sodium Oxalate & $\mathrm{Na}_{2} \mathrm{C}_{2} \mathrm{O}_{4}$ & 0.57 \\
\hline Water & $\mathrm{H}_{2} \mathrm{O}$ & 200 \\
\hline Mix thoroughly then Add & Formula & Mass Needed, grams \\
\hline Sodium Chromate & $\mathrm{Na}_{2} \mathrm{CrO}_{4}$ & 0.64 \\
\hline Sodium Carbonate & $\mathrm{Na}_{2} \mathrm{CO}_{3}$ & 78.98 \\
\hline Mix thoroughly then Add & Formula & Mass Needed, grams \\
\hline Sodium Nitrate & $\mathrm{NaNO}_{3}$ & 87.85 \\
\hline Sodium Nitrite & $\mathrm{NaNO}_{2}$ & 80.71 \\
\hline Water & $\mathrm{H}_{2} \mathrm{O}$ & 245.58 \\
\hline
\end{tabular}


WSRC-TR-2002-00040, REV. 0, SRT-RPP-2002-00012. REV. 0

The addition sequence used in Table 10 eliminates undesirable destruction of carbonate by the acidic compounds (acidic nitrates and acids) and prevents oxidation of the organic species by chromate. The analytical results for the AN-102 supernate simulant are described in the simulant validation section of this document.

\subsubsection{Entrained Solids Simulant}

The entrained solids in envelope $\mathrm{C}$ will experience the precipitation of strontium carbonate and manganese dioxide before being processed through a crossflow filter. Because the presence of the unwashed entrained solids may have an impact on the precipitation product, the entrained solids must represent the unwashed solids in the AN-102 supernate. The basis for the unwashed solids composition on a dried solids basis is shown in Table 11. The basis was derived from a recent AN-102 sample after removing the easily soluble nitrate, nitrite and chloride. ${ }^{7}$ The TIC value was converted to carbonate before formulating compounds to represent the entrained solids.

Table 11 Basis for AN-102 Unwashed Entrained Solids

\begin{tabular}{|c|c|}
\hline Component & Micrograms/gram unwashed dried solids \\
\hline $\mathbf{A l}$ & 113000 \\
\hline $\mathbf{B a}$ & 146 \\
\hline $\mathbf{C a}$ & 733 \\
\hline $\mathbf{C e}$ & 122 \\
\hline $\mathbf{C r}$ & 9000 \\
\hline $\mathbf{F}$ & 20100 \\
\hline $\mathbf{F e}$ & 6050 \\
\hline $\mathbf{L a}$ & 122 \\
\hline $\mathbf{M n}$ & 1310 \\
\hline $\mathbf{N a}$ & 319000 \\
\hline $\mathbf{N d}$ & 245 \\
\hline $\mathbf{N i}$ & 93 \\
\hline $\mathbf{O x a l a t e}$ & 151000 \\
\hline $\mathbf{P b}$ & 728 \\
\hline Phosphate & 43300 \\
\hline $\mathbf{S i}$ & 341 \\
\hline Sulfate & 35600 \\
\hline $\mathbf{T I C}$ & 58400 \\
\hline $\mathbf{W}$ & 979 \\
\hline $\mathbf{Z n}$ & 116 \\
\hline $\mathbf{Z r}$ & 221 \\
\hline & \\
\hline
\end{tabular}


The most significant species present in the unwashed solids were sodium, carbonate, oxalate, aluminum, phosphate, sulfate and fluoride. By definition, the entrained solids should be compounds of limited or low solubility. After reviewing various combinations of cations and anions based on the requirement of low or limited solubility, the formulation given in Table 12 was deemed the most reasonable composition while providing consistency with the associated waste solution. The compounds were also chosen based upon their industrial availability.

Table 12 Recipe for Unwashed AN-102 Entrained Solids Simulant

\begin{tabular}{|l|c|c|c|}
\hline \multicolumn{1}{|c|}{ Recipe For AN-102 Solids } & CAS \# & Formula & $\begin{array}{c}\text { grams/100 } \\
\text { grams of } \\
\text { entrained solids }\end{array}$ \\
\hline Sodium Carbonate Monohydrate & $5968-11-6$ & $\mathrm{Na}_{2} \mathrm{CO}_{3} \bullet \mathrm{H}_{2} \mathrm{O}$ & 42.71 \\
\hline Sodium Oxalate & $62-76-0$ & $\mathrm{Na}_{2} \mathrm{C}_{2} \mathrm{O}_{4}$ & 16.10 \\
\hline Aluminum Oxide & $1344-28-1$ & $\mathrm{Al}_{2} \mathrm{O}_{3}$ & 15.12 \\
\hline Sodium Phosphate Dodecahydrate & $10101-89-0$ & $\mathrm{Na}_{3} \mathrm{PO}_{4} \bullet 12 \mathrm{H}_{2} \mathrm{O}$ & 12.28 \\
\hline Sodium Sulfate & $7727-73-3$ & $\mathrm{Na}_{2} \mathrm{SO}_{4} \bullet 10 \mathrm{H}_{2} \mathrm{O}$ & 8.35 \\
\hline Sodium Fluoride & $7681-49-4$ & $\mathrm{NaF}$ & 3.15 \\
\hline Chromic Oxide & $1308-38-9$ & $\mathrm{Cr}_{2} \mathrm{O}_{3}$ & 0.93 \\
\hline Ferric Hydroxide & $1310-14-1$ & $\mathrm{FeOOH}_{3}$ & 0.68 \\
\hline Manganese Dioxide & $1313-13-9$ & $\mathrm{MnO}_{2}$ & 0.15 \\
\hline Calcium Oxalate Monohydrate & $5794-28-5$ & $\mathrm{CaC}_{2} \mathrm{O}_{4} \bullet \mathrm{H}_{2} \mathrm{O}$ & 0.13 \\
\hline Calcium Tungstate & $7790-75-2$ & $\mathrm{CaWO}_{4}$ & 0.11 \\
\hline Lead Sulfate & $7446-14-2$ & $\mathrm{PbSO}_{4}$ & 0.08 \\
\hline Silica & $7631-86-9$ & $\mathrm{SiO}_{2}$ & 0.05 \\
\hline Neodymium Oxalate & $28877-87-4$ & $\mathrm{Nd}_{2}\left(\mathrm{C}_{2} \mathrm{O}_{4}\right)_{3} \bullet 10 \mathrm{H}_{2} \mathrm{O}$ & 0.04 \\
\hline Barium Sulfate & $7727-43-7$ & $\mathrm{BaSO}_{4}$ & 0.02 \\
\hline Cerium Oxalate & $15750-47-7$ & $\mathrm{Ce}_{2}\left(\mathrm{C}_{2} \mathrm{O}_{4}\right)_{3} \bullet 9 \mathrm{H}_{2} \mathrm{O}$ & 0.02 \\
\hline Lanthanum Oxalate & $537-03-1$ & $\mathrm{La}_{2}\left(\mathrm{C}_{2} \mathrm{O}_{4}\right)_{3} \bullet 9 \mathrm{H}_{2} \mathrm{O}$ & 0.02 \\
\hline Zirconium Dioxide & $1314-23-4$ & $\mathrm{ZrO}_{2}$ & 0.02 \\
\hline Zinc Oxalate Dihydrate & $4255-07-6$ & $\mathrm{ZnC}_{2} \mathrm{O}_{4} \bullet 2 \mathrm{H}_{2} \mathrm{O}$ & 0.02 \\
\hline Nickel Oxide & $1313-99-1$ & $\mathrm{NiO}$ & 0.01 \\
\hline
\end{tabular}

Note: The weight percent entrained solids will be set by the task using the simulant.

Some of the compounds present in the largest amounts are expected to be dissolved during the Sr/TRU washing process.

Particle size information is not available for the entrained solids in actual AN-102 waste. Therefore, the basis used for the particle size of the entrained solids simulant was set to less than 325 mesh (smaller than 44 micron) based upon an agreement with the customer. The particle size of the entrained solids is expected to decline (become smaller) due to shearing 
during the SR/TRU mixing/filtration and due to dissolution during washing. Entrained solids loading will be determined by the tests that utilize the simulant.

\subsubsection{Simulant Validation}

\subsubsection{Chemical Composition Validation}

The first step in validation of the simulant is to determine whether the simulant basis (Table 3 ) is consistent with other sources of information for this waste within the WTP project.

Table 13 provides a comparison of the inorganic simulant basis to the batch LAW-4 (AN102) in the TFCOUP Appendix D, Table D-2. ${ }^{12}$

Table 13 AN-102 Simulant Basis Compared to AN-102 Composition from Reference 12

\begin{tabular}{|c|c|c|c|}
\hline Component & $\begin{array}{c}\text { Reference } 12 \\
\text { AN-102, } \\
\text { Moles/Liter }\end{array}$ & $\begin{array}{l}\text { AN-102 Simulant } \\
\text { Basis, Moles/Liter }\end{array}$ & $\begin{array}{c}\% \text { of Reference } 12 \\
\text { Value }\end{array}$ \\
\hline Aluminum & $5.40 \mathrm{E}-01$ & $5.44 \mathrm{E}-01$ & 101 \\
\hline Ammonium & 7.09E-03 & 9.76E-03 & 138 \\
\hline Boron & $3.47 \mathrm{E}-03$ & $4.07 \mathrm{E}-03$ & 117 \\
\hline Cadmium & $5.15 \mathrm{E}-04$ & $6.49 \mathrm{E}-04$ & 126 \\
\hline Calcium & $1.09 \mathrm{E}-02$ & $1.46 \mathrm{E}-02$ & 134 \\
\hline Carbonate & $1.19 \mathrm{E}+00$ & $1.09 \mathrm{E}+00$ & 92 \\
\hline Cesium & $8.88 \mathrm{E}-05$ & $1.43 \mathrm{E}-04$ & 161 \\
\hline Chloride & $1.15 \mathrm{E}-01$ & $1.62 \mathrm{E}-01$ & 141 \\
\hline Chromium & $5.53 \mathrm{E}-03$ & 5.79E-03 & 105 \\
\hline Cobalt & $1.84 \mathrm{E}-04$ & $6.79 \mathrm{E}-05$ & 37 \\
\hline Copper & $3.59 \mathrm{E}-04$ & $4.56 \mathrm{E}-04$ & 127 \\
\hline Fluoride & $9.49 \mathrm{E}-02$ & $1.08 \mathrm{E}-01$ & 114 \\
\hline Hydroxide & $5.06 \mathrm{E}-01$ & $4.75 \mathrm{E}-01$ & 94 \\
\hline Iron & $8.30 \mathrm{E}-04$ & $8.95 \mathrm{E}-04$ & 108 \\
\hline Lanthanum & $8.88 \mathrm{E}-06$ & $1.37 \mathrm{E}-04$ & 1543 \\
\hline Lead & $8.1 \mathrm{E}-04$ & $1.07 \mathrm{E}-03$ & 132 \\
\hline Manganese & $5.37 \mathrm{E}-04$ & $6.37 \mathrm{E}-04$ & 119 \\
\hline Molybdenum & 5.04E-04 & 5.63E-04 & 112 \\
\hline Neodymium & $3.78 \mathrm{E}-04$ & $2.63 \mathrm{E}-04$ & 70 \\
\hline Nickel & $6.52 \mathrm{E}-03$ & $8.50 \mathrm{E}-03$ & 130 \\
\hline Nitrate & $3.79 \mathrm{E}+00$ & $3.24 \mathrm{E}+00$ & 85 \\
\hline Nitrite & $1.95 \mathrm{E}+00$ & $1.72 \mathrm{E}+00$ & 88 \\
\hline Phosphate & $5.68 \mathrm{E}-02$ & $6.96 \mathrm{E}-02$ & 123 \\
\hline Potassium & $6.98 \mathrm{E}-02$ & $6.08 \mathrm{E}-02$ & 87 \\
\hline Silicon & $2.30 \mathrm{E}-03$ & $4.27 \mathrm{E}-04$ & 19 \\
\hline Sodium & $1.01 \mathrm{E}+01$ & $9.54 \mathrm{E}+00$ & 94 \\
\hline
\end{tabular}


WSRC-TR-2002-00040, REV. 0, SRT-RPP-2002-00012. REV. 0

\begin{tabular}{|l|c|c|c|}
\hline \multicolumn{1}{|c|}{ Component } & $\begin{array}{c}\text { Reference 12 } \\
\text { AN-102, } \\
\text { Moles/Liter }\end{array}$ & $\begin{array}{c}\text { AN-102 Simulant } \\
\text { Basis, Moles/Liter }\end{array}$ & $\begin{array}{c}\text { \% of Reference 12 } \\
\text { Value }\end{array}$ \\
\hline Strontium & $6.48 \mathrm{E}-05$ & $3.42 \mathrm{E}-05$ & 53 \\
\hline Sulfate & $1.82 \mathrm{E}-01$ & $1.57 \mathrm{E}-01$ & 86 \\
\hline TOC & $2.17 \mathrm{E}+00$ & $2.26 \mathrm{E}+00$ & 104 \\
\hline Tungsten & $1.00 \mathrm{E}-03$ & $1.09 \mathrm{E}-03$ & 109 \\
\hline Zinc & $8.36 \mathrm{E}-05$ & $9.18 \mathrm{E}-05$ & 110 \\
\hline Zirconium & $1.69 \mathrm{E}-04$ & $1.75 \mathrm{E}-04$ & 104 \\
\hline
\end{tabular}

Most of the transition metals are at slightly higher concentrations in the simulant basis than those in the TFCOUP. For the major species, sodium and the anions, the value in TFCOUP is larger. Comparing the composition on an equivalent sodium basis would have had the anions matching better but also shifted the transition metals to a higher percentage of the TFCOUP.

Test solutions of the undiluted simulant and diluted simulant were prepared using the general procedure shown in Table 10. After mixing for 24 hours the solution was filtered through a 0.45 -micron nylon filter and the supernate submitted for analysis. The wet (unwashed) solids were collected from the filters and submitted for x-ray diffraction (XRD) to determine the major phases present. The amount of undissolved solids recovered from the undiluted simulant was estimated at less than one weight percent.

The undiluted simulant produced two different types of solids, which were analyzed separately. The first type of solid was white and denser than the other solids. The second solid was finer and had a yellow-white color. The XRD analysis of the white solids tentatively identified the solids as Thermonatrite $\left(\mathrm{Na}_{2} \mathrm{CO}_{3} \bullet \mathrm{H}_{2} \mathrm{O}\right)$ and Natrophosphate $\left(\mathrm{Na}_{7} \mathrm{~F}\left(\mathrm{PO}_{4}\right)_{2}\left(\mathrm{H}_{2} \mathrm{O}\right)_{19}\right)$. The presence of sodium carbonate in the solids for the undiluted simulant implies that the solution is probably saturated in carbonate anion. Dilution of the simulant to the nominal starting conditions of the SR/TRU process should dissolve the sodium carbonate. The presence of the sodium carbonate solids matches the expected high level of carbonate (based on TIC) in the unwashed entrained solids shown in Table 11. The other compound detected is the double salt, sodium fluorophosphate, and may be the result of excessive fluoride levels. Analysis of fluoride by ion chromatography can produce high results due to interference from organic acids. The second type of solid found in the undiluted simulant was also analyzed by XRD. The tentatively identified compounds included the thermonatrite and the natrophosphate previously observed. Also identified were a second double salt, Kogarkoite $\left(\mathrm{Na}_{3} \mathrm{FSO}_{4}\right)$ and Nitratine $\left(\mathrm{NaNO}_{3}\right)$. The sodium nitrate observed by the XRD is expected to be due to the interstitial liquid within the filtered solids layer. The impact of these solids on the supernate composition is that the supernate should be low in fluoride, phosphate, sulfate and carbonate.

Considerably fewer solids (estimated at less than 0.5 weight $\%$ ) were obtained from the 6.5 molar simulant solution. The only compound detected by XRD was the fluorophosphate double salt, natrophosphate $\left(\mathrm{Na}_{7} \mathrm{~F}\left(\mathrm{PO}_{4}\right)_{2}\left(\mathrm{H}_{2} \mathrm{O}\right)_{19}\right)$ as shown in Figure 6. The vertical lines in 
Figure 6 indicate the positions where peaks are expected based upon the identified compound and the relative intensity of those peaks. The nearly perfect match with the identified compound indicates that practically no other insoluble solids were present. As expected, because the supernate was much more dilute, all of the carbonate was in solution.

Figure 6 Solids filtered from AN-102 simulant at 6.5 Molar Na

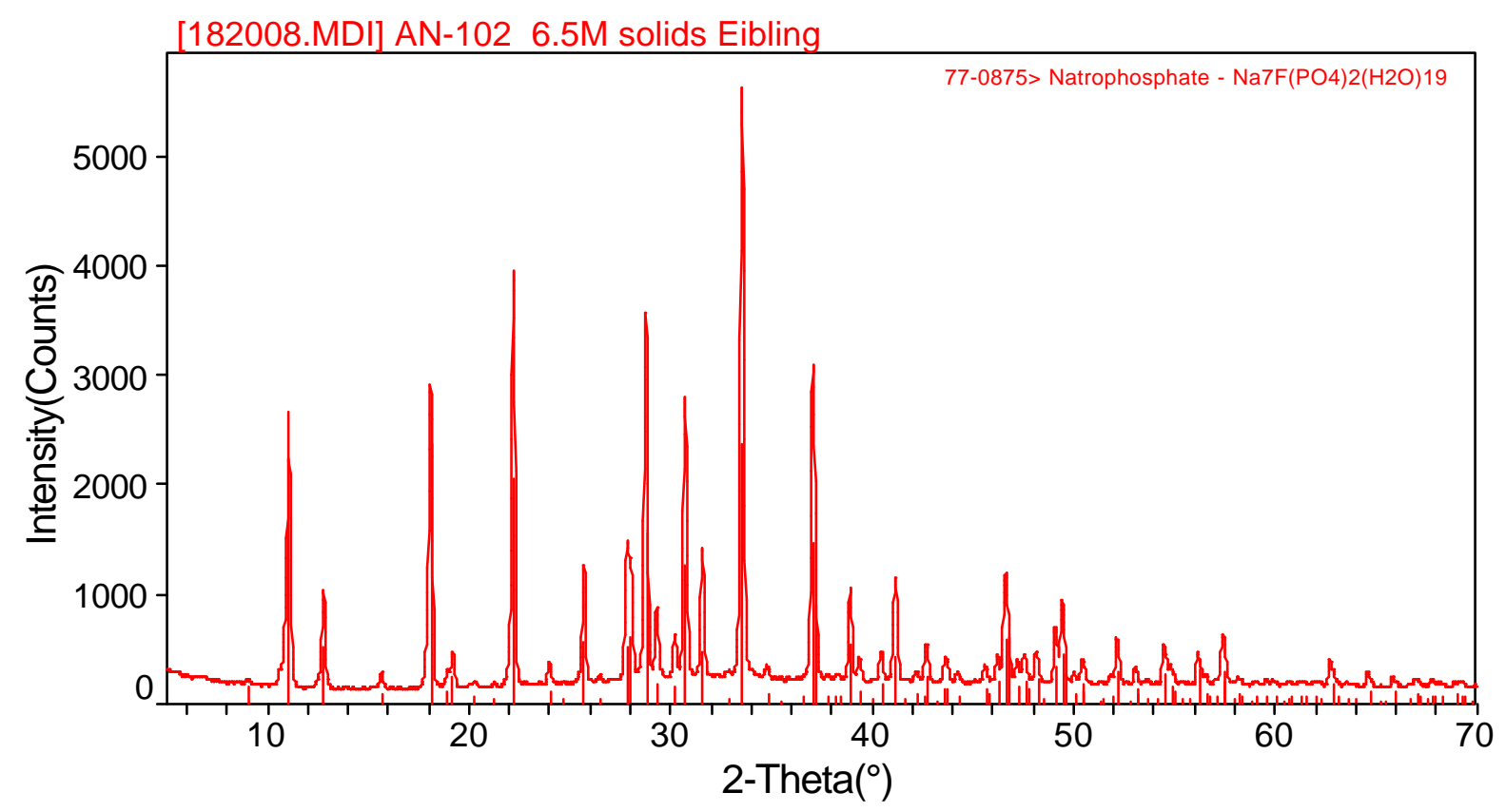

The analytical results for the filtered AN-102 supernate simulant listed in Table 14 and Table 15 were produced as previously described. The samples of the supernate were analyzed by inductively coupled plasma- emission spectroscopy (ICP-ES), ion chromatography (IC), ion exclusion chromatography (IEC), high performance liquid chromatography (HPLC), derivatization gas chromatography-mass spectrometry (GCMS), and total inorganic carbon/total organic carbon by persulfate oxidation (TIC/TOC). 
WSRC-TR-2002-00040, REV. 0, SRT-RPP-2002-00012. REV. 0

Table 14 Analytical Results for the Undiluted AN-102 Simulant (9.5 Molar Na)

\begin{tabular}{|c|c|c|c|c|c|c|c|}
\hline Sample ID & 182000 & 182001 & 182002 & Average & Target & & \\
\hline Component & $\mathrm{mg} / \mathrm{L}$ & $\mathrm{mg} / \mathrm{L}$ & $\mathrm{mg} / \mathrm{L}$ & $\mathrm{mg} / \mathrm{L}$ & $\mathrm{mg} / \mathrm{L}$ & $\%$ of Target & Method \\
\hline $\mathrm{Al}$ & 14600 & 14700 & 14700 & 14667 & 14680 & 100 & ICP-ES \\
\hline $\mathrm{B}$ & 40.3 & 41.8 & 41.9 & 41 & 44.0 & 94 & ICP-ES \\
\hline $\mathrm{Ca}$ & 371 & 379 & 380 & 377 & 587 & 64 & ICP-ES \\
\hline $\mathrm{Cd}$ & 68.1 & 70.1 & 68.8 & 69 & 73 & 95 & ICP-ES \\
\hline $\mathrm{Co}$ & 3.6 & 4.4 & 3.5 & 4 & 4 & 96 & ICP-ES \\
\hline $\mathrm{Cr}$ & 287 & 293 & 291 & 290 & 301 & 96 & ICP-ES \\
\hline $\mathrm{Cu}$ & 30.3 & 30.2 & 30.3 & 30 & 29.0 & 104 & ICP-ES \\
\hline $\mathrm{Fe}$ & 48.1 & 48.8 & 48.3 & 48 & 50.0 & 97 & ICP-ES \\
\hline $\mathrm{K}$ & 2700 & 2670 & 2800 & 2723 & 2378 & 115 & ICP-ES \\
\hline $\mathrm{La}$ & 14.9 & 14.6 & 14.8 & 15 & 19 & 78 & ICP-ES \\
\hline $\mathrm{Mn}$ & 34.0 & 34.5 & 34.2 & 34 & 35.000 & 98 & ICP-ES \\
\hline Mo & 49.3 & 53.0 & 50.6 & 51 & 54.0 & 94 & ICP-ES \\
\hline $\mathrm{Na}$ & 211000 & 217000 & 219000 & 215667 & 219390 & 98 & ICP-ES \\
\hline $\mathrm{Nd}$ & 40.0 & 39.1 & 39.9 & 40 & 38 & 104 & ICP-ES \\
\hline $\mathrm{Ni}$ & 470 & 485 & 476 & 477 & 499 & 96 & ICP-ES \\
\hline $\mathrm{P}$ & 697 & 720 & 699 & 705 & 2156 & 33 & ICP-ES \\
\hline $\mathrm{Pb}$ & 191 & 208 & 199 & 199 & 222 & 90 & ICP-ES \\
\hline $\mathrm{S}$ & 2870 & 2900 & 2900 & 2890 & 5033 & 57 & ICP-ES \\
\hline $\mathrm{Si}$ & 18.1 & 19.4 & 18.4 & 19 & 12 & 155 & ICP-ES \\
\hline $\mathrm{Sr}$ & 0.30 & 0.32 & 0.31 & 0.3 & 3 & 10 & ICP-ES \\
\hline $\mathrm{W}$ & 204 & 202 & 186 & 197 & 201 & 98 & ICP-ES \\
\hline $\mathrm{Zn}$ & 7.68 & 7.90 & 7.90 & 7.8 & 6 & 130 & ICP-ES \\
\hline $\mathrm{Zr}$ & 4.80 & 4.80 & 4.70 & 4.77 & 16 & 30 & ICP-ES \\
\hline Acetate & 1260 & 1300 & 1270 & 1277 & 925 & 138 & IEC \\
\hline Chloride & 5280 & 5190 & 5170 & 5213 & 5726 & 91 & IC \\
\hline Citrate & 3470 & 4000 & 1790 & 3087 & 5579 & 55 & IEC \\
\hline EDTA & 1740 & 1830 & 1880 & 1817 & 3318 & 55 & HPLC \\
\hline Fluoride & 1810 & 1830 & 1790 & 1810 & 2055 & 88 & IC \\
\hline Formate & 10300 & 10200 & 10200 & 10233 & 10070 & 102 & IC \\
\hline Formate & 17000 & 14800 & 13400 & 15067 & 10070 & 150 & IEC \\
\hline Glycolate & 11600 & 8370 & 7930 & 9300 & 12520 & 74 & IEC \\
\hline HEDTA & 73 & 71 & 75 & 73 & 440 & 17 & HPLC \\
\hline Iminodiacetic Acid & 8630 & 3480 & 5180 & 5763 & 5580 & 103 & GCMS \\
\hline Nitrate & 195000 & 189000 & 195000 & 193000 & 200640 & 96 & IC \\
\hline Nitrite & 79400 & 73800 & 88600 & 80600 & 79000 & 102 & IC \\
\hline Oxalate & 316 & 568 & 315 & 400 & 554 & 72 & IC \\
\hline Phosphate & 2430 & 2680 & 2450 & 2520 & 6610 & 38 & IC \\
\hline Sulfate & 8350 & 8300 & 10900 & 9183 & 15110 & 61 & IC \\
\hline Nitrilotriacetic Acid & 249 & 132 & 208 & 196 & 310 & 63 & GCMS \\
\hline TIC & 10600 & 10800 & 10600 & 10667 & 13140 & 81 & TIC/TOC \\
\hline TOC & 15200 & 14800 & 15200 & 15067 & 16245 & 93 & TIC/TOC \\
\hline Total Carbon & 25800 & 25600 & 25800 & 25733 & 29385 & 88 & TIC/TOC \\
\hline
\end{tabular}


WSRC-TR-2002-00040, REV. 0, SRT-RPP-2002-00012. REV. 0

Table 15 Analytical Results for the AN-102 Simulant at 6.5 M Na

\begin{tabular}{|c|c|c|c|c|c|c|c|}
\hline Sample ID & 182003 & 182004 & 182005 & Average & Target & & \\
\hline Component & $\mathrm{mg} / \mathrm{L}$ & $\mathrm{mg} / \mathrm{L}$ & $\mathrm{mg} / \mathrm{L}$ & $\mathrm{mg} / \mathrm{L}$ & $\mathrm{mg} / \mathrm{L}$ & \% of Target & Method \\
\hline $\mathrm{Al}$ & 9810 & 9850 & 9880 & 9847 & 10000 & 98 & ICP-ES \\
\hline $\mathrm{B}$ & 31.9 & 31.7 & 31.5 & 32 & 30 & 106 & ICP-ES \\
\hline $\mathrm{Ca}$ & 350 & 350 & 349 & 350 & 400 & 87 & ICP-ES \\
\hline $\mathrm{Cd}$ & 47.6 & 47.4 & 47.6 & 48 & 50 & 95 & ICP-ES \\
\hline $\mathrm{Cr}$ & 196 & 195 & 195 & 195 & 205 & 95 & ICP-ES \\
\hline $\mathrm{Cu}$ & 25.1 & 25 & 25.1 & 25 & 20 & 125 & ICP-ES \\
\hline $\mathrm{Fe}$ & 34.5 & 34.3 & 34.4 & 34 & 34 & 101 & ICP-ES \\
\hline $\mathrm{K}$ & 2030 & 1960 & 2030 & 2007 & 1620 & 124 & ICP-ES \\
\hline $\mathrm{La}$ & 13.3 & 13.3 & 13.5 & 13 & 13 & 103 & ICP-ES \\
\hline $\mathrm{Mn}$ & 22.3 & 22.2 & 22.3 & 22 & 24 & 93 & ICP-ES \\
\hline Mo & 44.3 & 43.9 & 43.6 & 44 & 37 & 119 & ICP-ES \\
\hline $\mathrm{Na}$ & 152000 & 150000 & 149000 & 150333 & 149434 & 101 & ICP-ES \\
\hline $\mathrm{Nd}$ & 23.6 & 23.7 & 24.5 & 24 & 26 & 92 & ICP-ES \\
\hline $\mathrm{Ni}$ & 324 & 323 & 322 & 323 & 340 & 95 & ICP-ES \\
\hline $\mathrm{P}$ & 661 & 655 & 656 & 657 & 1468 & 45 & ICP-ES \\
\hline $\mathrm{Pb}$ & 141 & 139 & 138 & 139 & 151 & 92 & ICP-ES \\
\hline $\mathrm{S}$ & 3520 & 3420 & 3420 & 3453 & 3430 & 101 & ICP-ES \\
\hline $\mathrm{Si}$ & 11.2 & 11.4 & 11.2 & 11 & 8 & 141 & ICP-ES \\
\hline $\mathrm{Sr}$ & 2.61 & 2.59 & 2.58 & 2.6 & 2 & 130 & ICP-ES \\
\hline $\mathrm{W}$ & 139 & 135 & 138 & 137 & 137 & 100 & ICP-ES \\
\hline $\mathrm{Zn}$ & 6 & 5.9 & 5.8 & 5.9 & 4 & 147 & ICP-ES \\
\hline $\mathrm{Zr}$ & 1.5 & 1.5 & 1.5 & 1.5 & 11 & 14 & ICP-ES \\
\hline Acetate & 791 & 814 & 808 & 804 & 630 & 128 & IEC \\
\hline Chloride & 3710 & 3720 & 3670 & 3700 & 3900 & 95 & IC \\
\hline Citrate & 1770 & 1790 & 1770 & 1777 & 3800 & 47 & IEC \\
\hline EDTA & 1040 & 913 & 987 & 980 & 2260 & 43 & HPLC \\
\hline Fluoride & 1930 & 1940 & 1890 & 1920 & 1400 & 137 & IC \\
\hline Formate & 6830 & 6890 & 6850 & 6857 & 6860 & 100 & IC \\
\hline Formate & 8640 & 15600 & 12400 & 12213 & 6860 & 178 & IEC \\
\hline Glycolate & 5020 & 4730 & 4370 & 4707 & 8530 & 55 & IEC \\
\hline HEDTA & 31 & 27 & 26 & 28 & 300 & 9 & HPLC \\
\hline Iminodiacetic Acid & 3700 & 3830 & 3550 & 3693 & 3655 & 101 & GCMS \\
\hline Nitrate & 126000 & 134000 & 133000 & 131000 & 136700 & 96 & IC \\
\hline Nitrilotriacetic Acid & 224 & 208 & 205 & 212 & 211 & 101 & GCMS \\
\hline Nitrite & 55600 & 60800 & 59200 & 58533 & 53800 & 109 & $\mathrm{IC}$ \\
\hline Oxalate & 341 & 352 & 482 & 392 & 377 & 104 & IC \\
\hline Phosphate & 2240 & 2250 & 2430 & 2307 & 4500 & 51 & IC \\
\hline Sulfate & 12200 & 10200 & 10200 & 10867 & 10290 & 106 & $\mathrm{IC}$ \\
\hline TIC & 7650 & 7580 & 7580 & 7603 & 8950 & 85 & TIC/TOC \\
\hline TOC & 10150 & 10420 & 10120 & 10230 & 11065 & 92 & TIC/TOC \\
\hline Total Carbon & 12800 & 18000 & 17700 & 16167 & 20015 & 81 & TIC/TOC \\
\hline
\end{tabular}

In general, the agreement between the measured concentration and the planned concentration for the transition and lanthanide metals is very good. Agreement for the major anions, nitrate 
and nitrite, is also very good. The supernate analysis for phosphorus and phosphate are fairly consistent and are low which is also consistent with the insoluble fluorophosphate species observed in the solids at both concentrations of simulant. The higher phosphate level measured in actual AN-102 supernate probably indicates that the actual fluoride level is lower than the level that has previously been reported. The fluoride analysis result, particularly in Table 15, demonstrates the presence of interfering components because fluoride should be low due to the precipitated fluorophosphate salt instead of high. Sulfate in the undiluted supernate is also low and confirms the precipitation of sulfate as the fluorosulfate salt. Other analyses showing evidence of interference are formate and carbonate by IEC and the interference is probably due to the complex nature of the AN-102 formulation (multitude of organic acids). The low result for HEDTA may be due to chemical degradation of the complexing agent as previously reported for caustic solutions. ${ }^{14-16}$

\subsubsection{Physical Property Validation}

\subsection{Density}

The density of the simulant was measured at several different sodium concentrations for comparison with actual AN-102 supernate densities. Table 16 compares the simulant density to the actual density at $25^{\circ} \mathrm{C}$ for diluted and undiluted supernate.

Table 16 Supernate Density at 25 Celsius

\begin{tabular}{|c|c|c|c|}
\hline \multicolumn{2}{|c|}{ Simulant } & \multicolumn{2}{c|}{ Actual AN-102 Sample ${ }^{6-8}$} \\
\hline $\mathrm{Na}$, Moles/Liter & $\mathrm{g} / \mathrm{mL}$ & $\mathrm{Na}$, Moles/Liter & $\mathrm{g} / \mathrm{mL}$ \\
\hline 6.5 & 1.30 & 6.4 & 1.33 \\
\hline 9.54 & 1.43 & Undiluted (8-10.4) & $1.41-1.47$ \\
\hline
\end{tabular}

During development of a prior envelope C simulant, for tank AN-107 supernate, Equation (1) which related the sodium concentration (X, molarity) to the density $(\mathrm{Y}, \mathrm{gm} / \mathrm{L})$ was empirically developed to allow predictions of densities for different sodium concentrations when the supernate is diluted:

$$
\mathrm{Y}^{2}=0.998+0.1054 \mathrm{X} \quad(1) .^{17}
$$

Equation (1) was tested to determine if it could also be applied to the AN-102. As shown in Table 17, Equation (1) can be used to predict the density of the simulant at a different sodium concentration. 
WSRC-TR-2002-00040, REV. 0, SRT-RPP-2002-00012. REV. 0

Table 17 Simulant Density Based on Empirical Equation

\begin{tabular}{|c|c|c|}
\hline $\begin{array}{c}\text { Simulant Na Concentration, } \\
\text { Moles/Liter }\end{array}$ & Measured Density, g/mL & Predicted Density, g/mL \\
\hline 4.016 & 1.192 & 1.192 \\
\hline 5.02 & 1.236 & 1.236 \\
\hline 6.024 & 1.278 & 1.278 \\
\hline 6.527 & 1.303 & 1.298 \\
\hline 7.53 & 1.34 & 1.339 \\
\hline 9.581 & 1.434 & 1.417 \\
\hline
\end{tabular}

\subsubsection{2 $\underline{\text { Rheology }}$}

The rheological properties of the diluted and undiluted supernate simulant were investigated using a Haake RS-150 rheometer. The samples were analyzed across the shear rate range of 0 to $8001 /$ seconds using the DG-41 (double gap) concentric cylindrical sensor at $25^{\circ} \mathrm{C}$. Figure 7 shows comparisons of the flow curves for duplicate runs at 6.5 molar $\mathrm{Na}$ and 9.58 molar $\mathrm{Na}$ to the linear regression lines from actual waste sample runs.

Figure 7 AN-102 Supernate Simulant Flow Curve Compared to Actual Waste

AN-102 Simulant Flow Curves Compared to Actual Waste

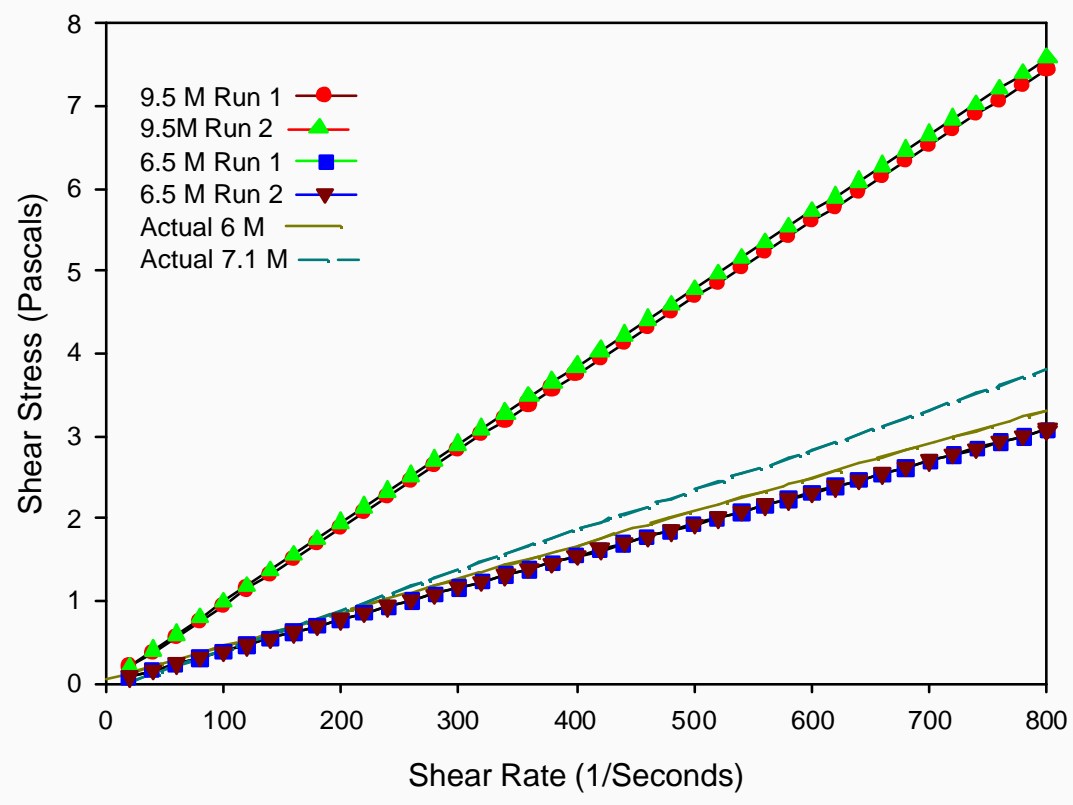


The actual waste samples were pretreated AN-102 samples and were run on a Haake RV20/M5 rheometer with the NV double-gap concentric, cylindrical sensor at $25^{\circ} \mathrm{C} .{ }^{13}$ The flow curves for both simulants and for the actual waste samples show that the liquids are Newtonian. For a Newtonian liquid, the ratio of shear stress to shear rate is a constant, which is the viscosity of the liquid. A comparison of the viscosity of the simulant to the pretreated AN-102 waste sample is shown in Table 18.

Table 18 Viscosity of AN-102 Simulant and Actual AN-102 Supernate at 25 Celsius

\begin{tabular}{|c|c|c|}
\hline Na, Moles/Liter & $\begin{array}{c}\text { Simulant Viscosity } \\
\text { milliPascarsec }\end{array}$ & $\begin{array}{c}\text { Actual AN-102 Viscosity } \\
\text { milliPascarsec }\end{array}$ \\
\hline 5 & $\mathrm{NM}$ & $2.9 \pm 1$ \\
\hline 6 & $\mathrm{NM}$ & $4 \pm 1$ \\
\hline 6.5 & 3.8 & $\mathrm{NM}$ \\
\hline 7 & $\mathrm{NM}$ & $5.1 \pm 1$ \\
\hline 9.54 & 9.4 & $\mathrm{NM}$ \\
\hline
\end{tabular}

$\mathrm{NM}=$ Not Measured

The agreement between the actual waste and the simulant is very good after allowing for the error factor listed for the waste sample.

\subsection{CONCLUSION/SUMMARY}

A formulation for a supernate simulant has been developed to represent waste from Hanford Tank 241-AN-102. The simulant is designed to reproduce the chemical composition of the supernate at 9.5 molar sodium and after the supernate is diluted to a 6.5 molar sodium concentration. The simulant also includes a formulation to represent the unwashed entrained solids expected in the undiluted supernate.

\subsection{REFERENCES}

1. Williams, M. R. Task Technical and Quality Assurance Plan In Support of RPP-WTP Pilot-Scale Precipitation Testing. WSRC-TR-2000-00496, Rev 1, SRT-RPP-200000050, Rev. 1, Savannah River Site, Aiken SC 29808 (November 30, 2001).

2. Poirier, M. R. Task Technical and Quality Assurance for AN-102 Simulant Sr/TRU Precipitation and Ultrafiltration. WSRC-TR-2001-Draft, SRT-RPP-2001-Draft, Rev 0, Savannah River Site, Aiken, SC 29808 (December 14,2001). 


\section{WSRC-TR-2002-00040, REV. 0,}

SRT-RPP-2002-00012. REV. 0

3. Bannochie, C., and C. Nash Evaluation of Post-Filtration Precipitation Mechanisms. WSRC-TR-2001-00425, SRT-RPP-2001-00147, Rev 0, Savannah River Site, Aiken, SC 29808 (November 12, 2001).

4. Bannochie, C. Complexant Identification in Hanford Waste Simulant Sr/TRU Filtrate. WSRC-TR-2001-00608, SRT-RPP-2001-00238, Rev B, Savannah River Site, Aiken, SC 29808 (December 17, 2001).

5. Josephs, J. E. and T. B. Calloway, Jr. Task Technical and Quality Assurance Plan forLAW Evaporation: Antifoam/Defoamer Testing for Low Activity Waste Solution. WSRCRP-2001-00791, SRT-RPP-2001-00142 Revision 0, Savannah River Site, Aiken, SC 29808 (December 1, 2001).

6. Hay, M. S., Bronikowski, M. G., Hsu, C. W., and T. L. White. Chemical Characterization of an Envelope C Sample from Hanford Tank 241-AN-102. USDOE Report BNF-003-98-0250, Rev 0, Savannah River Site, Aiken, SC 29808 (July 31, 2000).

7. Urie, M. W., Fiskum, S. K., Campbell, J. A., Farmer, O. T., Greenwood, L. R., Hoppe, E. W., Mong, G. M., Soderquist, C. Z., Swoboda, R. G., Thomas, M. P., and J. J. Wagner. Chemical Analysis and Physical Property Testing of 241-AN-102 Tank Waste-Supernatant and Centrifuged Solids. PNWD-3173, WTP-RPT-020, Pacific Northwest National Laboratory, Richland, WA 99352 (July, 2002).

8. Esch, R. A. Tank 241-AN-102 Low Activity Waste Envelope C Analytical Results for the Final Report. HNF-SD-WM-DP-310, Rev 0, Waste Management Federal Services of Hanford, Inc for Fluor Daniel Hanford, Inc., Richland, WA, (1998).

9. Jo, J., Morris, B. J., and T. T. Tran. Tank Characterization Report for Double-Shell Tank 241-AN-102. WHC-SD-WM-ER-545, Rev 1, Westinghouse Hanford Company, Richland, WA 99352 (August 1996).

10. Lokken, R.O., Scheele, R. D., Strachan, D. M., and A. P. Toste. Complex Concentrate Pretreatment FY 1986 Progress Report. PNL-7687, Pacific Northwest Laboratory, Richland, WA 99352 (September 1986).

11. Toste, A. P., Lechner-Fish, T. J., Hendren, D. J., Scheele, R. D., and W. G. Richmond. "Analysis of Organics in Highly Radioactive Nuclear Wastes". Journal of Radioanalytical and Nuclear Chemistry, 123, p 149 (1988).

12. Kirkbride, R. A., Allen, G. K., Higley, B. A., Hohl, T. M., Lambert, S. L., Orme, R. M., Pace, D. E., Seidl, J. A., Wittman, R. S., Baldwin, J. H., Jo, J. and J. N. Strode. Tank Farm Contractor Operation and Utilization Plan. HNF-SD-WM-SP-012 REV 3A, Numatec Hanford Corporation and CH2MHILL Hanford Group, Inc., Richland, WA (September 2001).

13. Zamecnik, J. R., Crawford, C. L., and D. C. Koopman. Large Scale Vitrification of 241 AN-102 (Envelope C) Sample. WSRC-TR-2002-00093, Rev.0, SRT-RPP-2001-00190, Rev. 0, Savannah River Site, Aiken, SC 29808 (May 31, 2002). 
14. Babad, H., Camaioni, D. M., Lilga, M. A., Samuels, W. D. and D. M. Strachan Tank Waste Chemistry - A New Understanding of Waste Aging. WHC-SA-1694-FP, Westinghouse Hanford Company, Richland, WA (February 1993).

15. Toste, A. P. and T. J. Lechner-Fish. "Chemo-Degradation of Chelating and Complexing Agents in a Simulated, Mixed Nuclear Waste". Proceedings of Waste Management'93, Tucson, AZ, Vol. 13, pp. 237-244 (1993).

16. Babad, H. and D. M. Camaioni. "The Aging of Organic Chemicals in Hanford HighLevel Wastes". Proceedings of Waste Management '00, Tucson, AZ, (2000).

17. Eibling, R. E. and C. Nash. Hanford Waste Simulants Created to Support the Research and Development on the River Protection Project - Waste Treatment Plant. WSRC-TR2000-00338, Rev.0, SRT-RPP-2000-00017, Rev. 0, Savannah River Site, Aiken, SC 29808 (July 26, 2001).

18. Final Environmental Statement, Waste Management Operations, Hanford Reservation, Richland, Washington. Volume 2. ERDA-1538 (Vol.2), Richland. WA (December 01, 1975). 


\section{APPENDIX A: AN-102 SUPERNATE AND ENTRAINED SOLIDS SIMULANT PREPARATION PROCEDURE}

\subsection{SIMULANT DESIGNATION}

The AN-102 supernate simulant replicates the chemical and physical properties of the Envelope C Hanford tank 241-AN-102 supernate diluted to 6.5 molar in sodium. The AN102 entrained solids simulant is designed to represent the unwashed entrained solids present in the supernate from Hanford tank 241-AN-102. The supernate simulant and entrained solids simulant are intended for use in testing the Sr/TRU precipitation and filtration pretreatment processes. The simulant recipes were formulated based upon the actual tank waste analyses of diluted and undiluted $\mathrm{AN}-102$ waste.

\subsection{SIMULANT WASTE STREAM COMPOSITION AND UNIT OPERATION USAGE}

\subsection{CHARACTERIZATION DATA DESCRIPTION}

The AN-102 supernate simulant was developed to replicate the chemical and physical properties of the actual AN-102 supernate diluted to 6.5 molar Na. The simulant metals and anionic constituents' concentrations are to agree with actual waste concentrations within $\pm 10 \%$, or within analytical error of the method as determined by inductively coupled plasma atomic emission spectrometry (ICPAES), inorganic ion chromatography (IC), gas chromatography-mass spectrometry (GCMS) and other organic characterization methods. Density is determined gravimetrically. Viscosity is determined as a function of temperature.

The AN-102 entrained solids simulant was developed to represent the types of compounds expected to be present in the unwashed solids entrained in the AN-102 supernate.

\subsection{FLOWSHEET OPERATION FOR WHICH THE SIMULANT WAS DEVELOPED}

The AN-102 supernate and entrained solids simulants are intended to support the Sr/TRU precipitation process, crossflow filtration process and waste feed evaporation pretreatment studies. The close match in rheological behavior of the supernate simulant and actual waste also makes it a good candidate as a rheological simulant. 


\subsection{ACTUAL SIMULANT PREPARATION PROCEDURE}

\subsection{CHEMICALS TO USE}

Reagent-grade nonradioactive compounds were chosen to match the chemical composition of the AN-102 waste. Cost, chemical availability, and ease of scale up were considered in choosing which chemicals to use.

The metals are primarily added as the metal nitrates due to their high solubility and availability. Many of these salts contain waters of hydration and the specific form to be used is shown in Table A-1. Care must be taken in storing and using some of these compounds due to their tendency to readily absorb water. Using a salt, which has obviously absorbed excess water, will lead to missing the target value for that metal. When necessary, a solution of the metal nitrate can be used. However, the water additions shown in Table A-1 will have to be appropriately reduced to account for the water in the metal nitrate solution. Chromium, molybdenum and tungsten are added as the chromate, molybdate and tungstate salts matching the soluble properties of the measured species in the waste.

The complexing agents are generally added as the free acid form or as the sodium salt of the acid. Boric acid is used for boron because the expected form of boron in the waste is as the borate anion. The remainder of the anions are added as the sodium salt.

The entrained solids simulant was formulated with very low-solubility or limited-solubility compounds that are easily obtained. The recommended particle size for the solids is less than 44 micron (smaller than 325 mesh).

All radioactive components are deleted from both simulant compositions. Radioactive Cs was replaced with non-radioactive $\mathrm{Cs}$, which was added at the total Cs concentration. Radioactive $\mathrm{Sr}$ was replaced with non-radioactive $\mathrm{Sr}$, which was added at the total $\mathrm{Sr}$ concentration. No appropriate surrogate for $\mathrm{U}$ or the other transuranics was identified.

\subsection{CHEMICAL ADDITION ORDER}

The order of chemical addition to produce the supernate simulant is shown in Table A-1 and is based upon the following logical steps:

- Prepare solution of metal nitrates.

- Add acid-stable complexing agents and acid stable salts.

- Convert solution from acid to base by addition of sodium hydroxide and selected basic salts.

- Add base-stable salts and complexing agents.

These steps produce the desired complexes expected in the waste simulant while avoiding the acid-induced decomposition of carbonate or nitrite or oxidation-reduction reactions between reducing species such as formate, glycolate or oxalate and the transition metals. 
The water used for the simulant should be deionized water to limit the addition of other uncontrolled species. The mass of water added in each step is based upon producing a simulant solution with a total $\mathrm{Na}$ concentration of 6.5 molar and a solution density of 1.303 $\mathrm{g} / \mathrm{mL}$ at $25^{\circ} \mathrm{C}$.

Table A- 1 Chemical Addition Order and Amounts for Producing One Liter of the AN-102 Supernate Simulant at 6.5 M Na

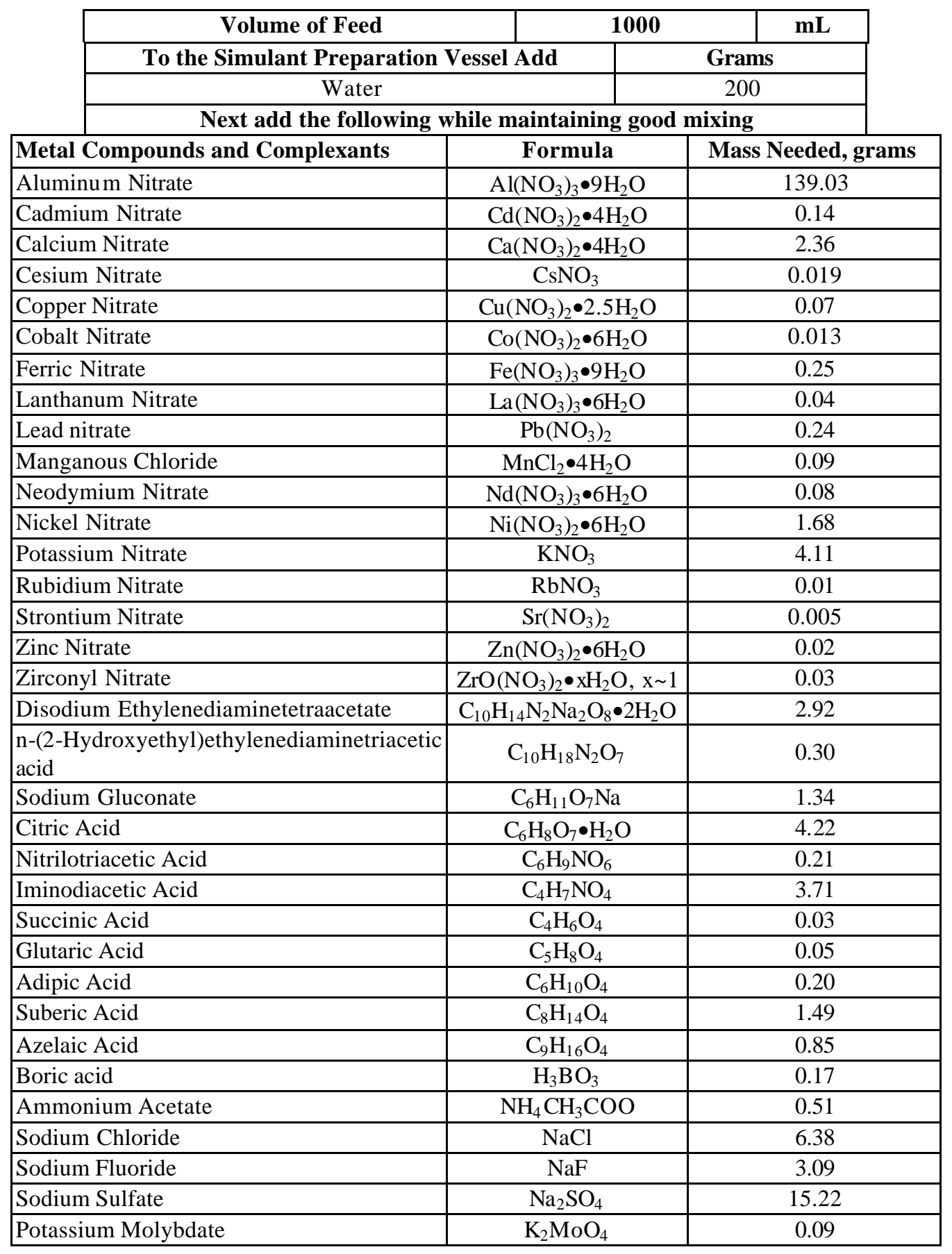


WSRC-TR-2002-00040, REV. 0, SRT-RPP-2002-00012. REV. 0

\begin{tabular}{|l|c|c|}
\hline $\begin{array}{l}\text { Mix thoroughly. Then add the following } \\
\text { while mixing. }\end{array}$ & Formula & Mass Needed, grams \\
\hline Sodium Hydroxide & $\mathrm{NaOH}$ & 79.31 \\
\hline Sodium Phosphate & $\mathrm{Na}_{3} \mathrm{PO}_{4} \bullet 12 \mathrm{H}_{2} \mathrm{O}$ & 18.01 \\
\hline Sodium Tungstate & $\mathrm{Na}_{2} \mathrm{WO}_{4} \bullet 2 \mathrm{H}_{2} \mathrm{O}$ & 0.25 \\
\hline Sodium Metasilicate & $\mathrm{Na}_{2} \mathrm{SiO}_{3} \bullet 9 \mathrm{H}_{2} \mathrm{O}$ & 0.08 \\
\hline Sodium Glycolate & $\mathrm{HOCH} C \mathrm{CONa}$ & 11.14 \\
\hline Sodium formate & $\mathrm{NaHCOO}$ & 10.36 \\
\hline Sodium Acetate & $\mathrm{NaCH}_{3} \mathrm{COO} \bullet 3 \mathrm{H}_{2} \mathrm{O}$ & 0.55 \\
\hline Sodium Oxalate & $\mathrm{Na}_{2} \mathrm{C}_{2} \mathrm{O}_{4}$ & 0.57 \\
\hline Water & $\mathrm{H}_{2} \mathrm{O}$ & 200 \\
\hline Mix thoroughly then Add & $\mathbf{F o r m u l a}$ & Mass Needed, grams \\
\hline Sodium Chromate & $\mathrm{Na}_{2} \mathrm{CrO}_{4}$ & 0.64 \\
\hline Sodium Carbonate & $\mathrm{Na}_{2} \mathrm{CO}_{3}$ & 78.98 \\
\hline Mix thoroughly then Add & $\mathbf{F o r m u l a}$ & Mass Needed, grams \\
\hline Sodium Nitrate & $\mathrm{NaNO}_{3}$ & 87.85 \\
\hline Sodium Nitrite & $\mathrm{NaNO}_{2}$ & 80.71 \\
\hline Water & $\mathrm{H}_{2} \mathrm{O}$ & 245.58 \\
\hline \multicolumn{2}{|c|}{ Mix thoroughly for $\mathbf{2 4}$ hours. } & \\
\hline
\end{tabular}

The order of addition for the chemicals needed to produce the entrained solids simulant is not an issue. Instead, the entrained solids simulant must be prepared by adding the compounds to a completed AN-102 supernate simulant. The compounds to add are shown in Table A-2 in terms of grams of each compound per 100 grams of entrained solids. The weight percent entrained solids loading should be specified by the specific task that will use the simulant.

Table A- 2 AN-102 Entrained Solids Simulant Formulation

\begin{tabular}{|l|c|c|c|}
\hline \multicolumn{1}{|c|}{ Recipe For AN-102 Solids } & CAS \# & Formula & $\begin{array}{c}\text { grams/100 } \\
\text { grams of } \\
\text { entrained solids }\end{array}$ \\
\hline Sodium Carbonate Monohydrate & $5968-11-6$ & $\mathrm{Na}_{2} \mathrm{CO}_{3} \bullet \mathrm{H}_{2} \mathrm{O}$ & 42.71 \\
\hline Sodium Oxalate & $62-76-0$ & $\mathrm{Na}_{2} \mathrm{C}_{2} \mathrm{O}_{4}$ & 16.10 \\
\hline Aluminum Oxide & $1344-28-1$ & $\mathrm{Al}_{2} \mathrm{O}_{3}$ & 15.12 \\
\hline Sodium Phosphate Dodecahydrate & $10101-89-0$ & $\mathrm{Na}_{3} \mathrm{PO}_{4} \bullet 12 \mathrm{H}_{2} \mathrm{O}$ & 12.28 \\
\hline Sodium Sulfate & $7727-73-3$ & $\mathrm{Na}_{2} \mathrm{SO}_{4} \bullet 10 \mathrm{H}_{2} \mathrm{O}$ & 8.35 \\
\hline Sodium Fluoride & $7681-49-4$ & $\mathrm{NaF}$ & 3.15 \\
\hline Chromic Oxide & $1308-38-9$ & $\mathrm{Cr}_{2} \mathrm{O}_{3}$ & 0.93 \\
\hline Ferric Hydroxide & $1310-14-1$ & $\mathrm{FeOH}$ & 0.68 \\
\hline Manganese Dioxide & $1313-13-9$ & $\mathrm{MnO}_{2}$ & 0.15 \\
\hline Calcium Oxalate Monohydrate & $5794-28-5$ & $\mathrm{CaC}_{2} \mathrm{O}_{4} \bullet \mathrm{H}_{2} \mathrm{O}$ & 0.13 \\
\hline Calcium Tungstate & $7790-75-2$ & $\mathrm{CaWO}_{4}$ & 0.11 \\
\hline Lead Sulfate & $7446-14-2$ & $\mathrm{PbSO}_{4}$ & 0.08 \\
\hline Silica & $7631-86-9$ & $\mathrm{SiO}_{2}$ & 0.05 \\
\hline Neodymium Oxalate & $28877-87-4$ & $\mathrm{Nd}_{2}\left(\mathrm{C}_{2} \mathrm{O}_{4}\right)_{3} \bullet 10 \mathrm{H}_{2} \mathrm{O}$ & 0.04 \\
\hline
\end{tabular}


WSRC-TR-2002-00040, REV. 0, SRT-RPP-2002-00012. REV. 0

\begin{tabular}{|l|c|c|c|}
\hline \multicolumn{1}{|c|}{ Recipe For AN-102 Solids } & CAS \# & Formula & $\begin{array}{c}\text { grams/100 } \\
\text { grams of } \\
\text { entrained solids }\end{array}$ \\
\hline Barium Sulfate & $7727-43-7$ & $\mathrm{BaSO}_{4}$ & 0.02 \\
\hline Cerium Oxalate & $15750-47-7$ & $\mathrm{Ce}_{2}\left(\mathrm{C}_{2} \mathrm{O}_{4}\right)_{3} \bullet 9 \mathrm{H}_{2} \mathrm{O}$ & 0.02 \\
\hline Lanthanum Oxalate & $537-03-1$ & $\mathrm{La}_{2}\left(\mathrm{C}_{2} \mathrm{O}_{4}\right)_{3} \bullet 9 \mathrm{H}_{2} \mathrm{O}$ & 0.02 \\
\hline Zirconium Dioxide & $1314-23-4$ & $\mathrm{ZrO}_{2}$ & 0.02 \\
\hline Zinc Oxalate Dihydrate & $4255-07-6$ & $\mathrm{ZnC}_{2} \mathrm{O}_{4} \bullet 2 \mathrm{H}_{2} \mathrm{O}$ & 0.02 \\
\hline Nickel Oxide & $1313-99-1$ & $\mathrm{NiO}$ & 0.01 \\
\hline
\end{tabular}

\subsection{PRECAUTIONS}

- Material Safety Data Sheets (MSDS) should be reviewed for all of the compounds in the simulant formulation.

- Appropriate safety apparel (acid-resistant gloves, etc) should be worn when working with chemicals as specified in the MSDS.

- Addition of the transition metal nitrates to the initial solution will produce a very acidic solution.

- Addition of the $\mathrm{NaOH}$ results in significant heat generation. The $\mathrm{NaOH}$ can be added slowly allowing heat to dissipate, or the mixing container can be cooled by use of an external or internal cooling system (ice bath, cooling coils, etc).

- During the initial stages of sodium hydroxide addition, significant $\mathrm{Al}$ solids form. Mixing may become difficult at this point. The $\mathrm{Al}$ solids will return to solution when $\mathrm{pH} \sim 9$ is exceeded.

- The carbonate salts are added after the $\mathrm{NaOH}$ to avoid carbonate decomposition.

- The sodium formate and sodium glycolate are added after the $\mathrm{NaOH}$ to prevent any redox reactions from occurring. The acid forms (formic acid and glycolic acid) are fairly strong reducing agents and can react with nitric acid and other possible oxidizers such as some of the transition metals.

- The sodium chromate is also added after the $\mathrm{NaOH}$. In acid, the chromate converts to dichromate, which is a very strong oxidizer and can react with acetate, formate, glycolate, citrate, oxalate and other organic species in the simulant.

- Addition of sodium nitrite must be made after the addition of sodium hydroxide to avoid generation of $\mathrm{NO}_{\mathrm{x}}$ vapors. 


\subsection{OTHER CONSIDERATIONS}

The supernate simulant can be filtered through a $0.45 \mu \mathrm{m}$ filter to remove the sodium fluorophosphate solids if the simulant is needed for some purpose other than the $\mathrm{Sr}$ /TRU process studies. However, if the simulant is for precipitation studies then prefiltering the simulant is unnecessary.

The simulant should be stored in a polyethylene container (or equivalent). Storage in glass may result in etching of the glass.

The shelf life for this simulant has not been fully evaluated. However, based on appearance of a film on the bottles after several months, the slow decomposition of the less stable complexes may be occurring.

\subsection{KEY CHARACTERISTICS AND LIMITATIONS OF AN-102 SUPERNATE SIMULANT}

\subsection{KEY CHARACTERISTICS}

The simulant composition is to match major, minor, and trace constituents of actual AN-102 waste diluted to $6.5 \mathrm{M} \mathrm{Na}$. Of specific concern are the constituents that affect the $\mathrm{Sr} / \mathrm{TRU}$ precipitation processing parameters. These constituents include the $\mathrm{Na}, \mathrm{Sr}, \mathrm{OH}^{-}$, and $\mathrm{CO}_{3}{ }^{-2}$ concentrations. Solution density and viscosity are also process-affecting (Townson, 2001).

\subsection{LIMITATIONS}

The simulant limitations are based primarily on chemical composition.

- Fluoride concentration may be excessive in the supernate simulant due to potential interferences in the fluoride measurements for Envelope $\mathrm{C}$ wastes.

- Envelope $\mathrm{C}$ wastes contain very high levels of organic carbon due to the presence of complexants and their decomposition products. Only about 50-55\% of the TOC in the actual AN-102 is accounted for in the AN-102 simulant. The incomplete organic constituent reconstruction may have an effect on the minor and/or trace cation solubilities and behavior. In addition, application of the AN102 simulant to LAW vitrification studies may require the careful selection of additional organic compounds to increase the TOC loading.

These uncertainties are not expected to cause significant performance variability for filtration processing activities. 


\subsection{VALIDATION OF THE SIMULANT}

Validating simulants includes determining chemical composition, physical properties, rheological properties, and process performance (Townson 2001). The simulant chemical composition was evaluated from three independent measurements relative to four independent analyses of actual AN-102 tank waste supernate. Major, minor, and trace analyte compositions in the simulant were to match the actual waste composition to within $\pm 10 \%$ or within the analytical uncertainty of the analysis method. Physical-property testing specifically included density, again in comparison to actual AN-102 tank supernate. The rheological properties were tested similarly to the AN-102 diluted-feed tank waste that was processed through the small-scale pretreatment unit operations.

\subsection{CHEMICAL COMPOSITION}

The measured concentrations of the major constituents for the supernate simulant (present at $>0.1$ molar) compared very well with the planned simulant composition. The major species, which included $\mathrm{Na}, \mathrm{Al}, \mathrm{Cl}$, formate, $\mathrm{NO}_{3}{ }^{-}, \mathrm{NO}_{2}{ }^{-}$, and $\mathrm{SO}_{4}{ }^{-2}$, were within 10 percent of the target value and the carbonate was within 15 percent of the target value. The only major species that missed the target value was glycolate based upon an analytical result that may be problematic and needs more work. Hydroxide which was also present at $>0.1$ molar was not measured.

Most of the minor and trace species, present at less than 0.1 molar, also compared favorably with the target values. These minor and trace species that were within $10 \%$ of target values included $\mathrm{B}, \mathrm{Cd}, \mathrm{Cr}, \mathrm{Fe}, \mathrm{La}, \mathrm{Mn}, \mathrm{Nd}, \mathrm{Ni}, \mathrm{Pb}, \mathrm{W}$, iminodiacetic acid, nitrilotriacetic acid, oxalate and total organic carbon. Minor and trace species that were within $25 \%$ of target values included $\mathrm{Ca}, \mathrm{Cu}, \mathrm{K}$ and Mo. Analytical measurements of some of the complexing agents such as EDTA and HEDTA produce highly variable results and additional analytical measurement work is probably necessary. Two of the minor species, fluoride and phosphate, are definitely off of their target values and this is consistent with the production of an insoluble fluorophosphate salt, natrophosphate.

Undissolved solids (UDS) were formed as a by-product of the supernate simulant preparation. The solids were analyzed by XRD and were primarily sodium fluorophosphate, $\mathrm{Na} 7 \mathrm{~F}\left(\mathrm{PO}_{4}\right)_{2}\left(\mathrm{H}_{2} \mathrm{O}\right)_{19}$, also known as natrophosphate. Simulant preparations at higher $\mathrm{Na}$ concentrations also produced additional insoluble compounds based upon XRD and these included sodium carbonate (thermonatrite $\left(\mathrm{Na}_{2} \mathrm{CO}_{3} \bullet \mathrm{H}_{2} \mathrm{O}\right)$ ), sodium fluorosulfate (kogarkoite $\left(\mathrm{Na}_{3} \mathrm{FSO}_{4}\right)$ ), and sodium nitrate. After filtration, no additional solids were observed.

The entrained solids simulant composition was not analyzed for chemical composition due to the problems with sampling and characterization of very dilute insoluble solids systems. Instead, the composition is administratively controlled to insure that all additions are made to the supernate in the correct amounts. Verification that all of the compounds in the entrained solids have been added to the supernate simulant are required when producing an AN-102 entrained solids simulant. 
WSRC-TR-2002-00040, REV. 0, SRT-RPP-2002-00012. REV. 0

\subsection{CHARGE BALANCING}

The anionic and cationic species present in the targeted AN-102 simulant composition was charge-balanced and a summary of the charges and the balance are shown in Table A- 3

Table A- 3 Charge Balance for AN-102 Supernate Simulant at 6.5 M Na

\begin{tabular}{|c|c|c|c|c|c|c|c|}
\hline \multicolumn{4}{|c|}{ Cations } & \multicolumn{4}{|c|}{ Anions } \\
\hline Species & Charge & Moles/Liter & $\begin{array}{l}\text { Charge, } \\
\text { moles/Liter }\end{array}$ & Species & Charge & Moles/Liter & $\begin{array}{l}\text { Charge, } \\
\text { moles/Liter }\end{array}$ \\
\hline Ammonium & 1 & $6.65 \mathrm{E}-03$ & $6.65 \mathrm{E}-03$ & Acetate & -1 & $1.07 \mathrm{E}-02$ & $-1.07 \mathrm{E}-02$ \\
\hline Barium & 2 & $0.00 \mathrm{E}+00$ & $0.00 \mathrm{E}+00$ & Aluminum & -1 & $3.71 \mathrm{E}-01$ & $-3.71 \mathrm{E}-01$ \\
\hline Cadmium & 2 & $4.42 \mathrm{E}-04$ & $8.85 \mathrm{E}-04$ & Boron & -3 & $2.77 \mathrm{E}-03$ & $-8.32 \mathrm{E}-02$ \\
\hline Calcium & 2 & $9.98 \mathrm{E}-03$ & $2.00 \mathrm{E}-02$ & Carbonate & -2 & $7.45 \mathrm{E}-01$ & $-1.49 \mathrm{E}+00$ \\
\hline Cerium & 3 & $0.00 \mathrm{E}+00$ & $0.00 \mathrm{E}+00$ & Chloride & -1 & $1.10 \mathrm{E}-01$ & $-1.10 \mathrm{E}-01$ \\
\hline Cesium & 1 & $9.74 \mathrm{E}-05$ & $9.74 \mathrm{E}-05$ & Chromium & -2 & $3.94 \mathrm{E}-03$ & $-7.89 \mathrm{E}-03$ \\
\hline Cobalt & 2 & $4.62 \mathrm{E}-05$ & $9.25 \mathrm{E}-05$ & $\begin{array}{c}\text { Ethylenediaminet } \\
\text { etraacetate }\end{array}$ & -4 & $7.84 \mathrm{E}-03$ & $-3.14 \mathrm{E}-02$ \\
\hline Copper & 2 & $3.11 \mathrm{E}-04$ & $6.22 \mathrm{E}-04$ & Fluoride & -1 & $7.37 \mathrm{E}-02$ & $-7.37 \mathrm{E}-02$ \\
\hline Iron & 3 & $6.10 \mathrm{E}-04$ & $1.83 \mathrm{E}-03$ & Formate & -1 & $1.52 \mathrm{E}-01$ & $-1.52 \mathrm{E}-01$ \\
\hline Lanthanum & 3 & $9.32 \mathrm{E}-05$ & $2.79 \mathrm{E}-04$ & Glycolate & -1 & $1.14 \mathrm{E}-01$ & $-1.14 \mathrm{E}-01$ \\
\hline Lead & 2 & $7.30 \mathrm{E}-04$ & $1.46 \mathrm{E}-03$ & Hydroxide & -1 & $3.23 \mathrm{E}-01$ & $-3.23 \mathrm{E}-01$ \\
\hline Magnesium & 1 & $0.00 \mathrm{E}+00$ & $0.00 \mathrm{E}+00$ & Molybdenum & -2 & $3.83 \mathrm{E}-04$ & $-7.67 \mathrm{E}-04$ \\
\hline Manganese & 2 & 4.34E-04 & $8.68 \mathrm{E}-04$ & $\begin{array}{l}\mathrm{n}- \\
\text { Hydroxyethylene } \\
\text { diaminetriacetate }\end{array}$ & -3 & $1.09 \mathrm{E}-03$ & $-3.27 \mathrm{E}-03$ \\
\hline Neodymium & 3 & $1.79 \mathrm{E}-04$ & $5.38 \mathrm{E}-04$ & Nitrate & -1 & $2.20 \mathrm{E}+00$ & $-2.20 \mathrm{E}+00$ \\
\hline Nickel & 2 & $5.79 \mathrm{E}-03$ & $1.16 \mathrm{E}-02$ & Nitrite & -1 & $1.17 \mathrm{E}+00$ & $-1.17 \mathrm{E}+00$ \\
\hline Potassium & 1 & $4.14 \mathrm{E}-02$ & $4.14 \mathrm{E}-02$ & Oxalate & -2 & $4.29 \mathrm{E}-03$ & $-8.57 \mathrm{E}-03$ \\
\hline Rubidium & 1 & 7.97E-05 & 7.97E-05 & Phosphate & -3 & 4.74E-02 & $-1.42 \mathrm{E}-01$ \\
\hline Sodium & 1 & $6.50 \mathrm{E}+00$ & $6.50 \mathrm{E}+00$ & Silicon & -2 & $2.91 \mathrm{E}-04$ & $-5.82 \mathrm{E}-04$ \\
\hline Strontium & 2 & $2.33 \mathrm{E}-05$ & $4.66 \mathrm{E}-05$ & Sulfate & -2 & $1.07 \mathrm{E}-01$ & $-2.14 \mathrm{E}-01$ \\
\hline Zirconium & 4 & $1.19 \mathrm{E}-04$ & $4.78 \mathrm{E}-04$ & Tungsten & -2 & $7.45 \mathrm{E}-04$ & $-1.49 \mathrm{E}-03$ \\
\hline $\begin{array}{c}\text { Sodium } \\
\text { Gluconate }\end{array}$ & 0 & $6.15 \mathrm{E}-03$ & $0.00 \mathrm{E}+00$ & Zinc & -2 & $6.25 \mathrm{E}-05$ & $-1.25 \mathrm{E}-04$ \\
\hline & & & & Nitrilotriacetate & -3 & $1.12 \mathrm{E}-03$ & $-3.37 \mathrm{E}-03$ \\
\hline & & & & Citric Acid & -3 & $2.01 \mathrm{E}-02$ & $-6.03 \mathrm{E}-02$ \\
\hline & & & & Iminodiacetate & -2 & $2.79 \mathrm{E}-02$ & $-5.58 \mathrm{E}-02$ \\
\hline & & & & Succinic Acid & -2 & $2.52 \mathrm{E}-04$ & $-5.05 \mathrm{E}-04$ \\
\hline & & & & Glutaric Acid & -2 & $4.08 \mathrm{E}-04$ & $-8.17 \mathrm{E}-04$ \\
\hline & & & & Adipic Acid & -2 & $1.39 \mathrm{E}-03$ & $-2.78 \mathrm{E}-03$ \\
\hline & & & & Azelaic Acid & -2 & $4.51 \mathrm{E}-03$ & $-9.02 \mathrm{E}-03$ \\
\hline & & & & Suberic Acid & -2 & $8.57 \mathrm{E}-03$ & $-1.71 \mathrm{E}-02$ \\
\hline & & & & $\begin{array}{c}\text { Sodium } \\
\text { Gluconate }\end{array}$ & 0 & $6.15 \mathrm{E}-03$ & $0.00 \mathrm{E}+00$ \\
\hline \multicolumn{2}{|c|}{ Total Plus Charge } & & 6.59 & \multicolumn{2}{|c|}{ Total Minus Charge } & & -6.58 \\
\hline
\end{tabular}


Careful attention was given to the ionic form of each component added to the simulant as well as to simulant chemistry at the time the component was added. The addition sequence was designed to produce the expected chemical species in the simulant such as the complexes of the alkaline earth and transition metals with the organic complexants. Chromate was added after shifting the $\mathrm{pH}$ to basic conditions to maintain $\mathrm{Cr}$ in the +6 oxidation state. The organic species, which can act as acidic reductants, were added to the caustic solution as sodium salts to prevent unwanted oxidation state changes. Phosphorous is expected to be present in tank waste as phosphate and was thus added as phosphate.

Development of the entrained solids simulant focused on mass balance for the major species (especially for sodium) in determining the compounds to use in the simulant.

\subsection{SIMULANT PROPERTIES COMPARED TO ACTUAL WASTE PROPERTIES}

Good agreement was obtained with the actual waste supernate and supernate simulant densities. The measured density of the AN-102 diluted simulant at 6.5 Molar Na was 1.33 $\mathrm{g} / \mathrm{mL}$ while the actual untreated AN-102 supernate diluted to 6.4 molar Na was $1.30 \mathrm{~g} / \mathrm{mL}$.

The rheograms of the waste and the simulant indicate that the fluids are Newtonian in behavior since they are linear with the shear rate versus shear stress relationship passing through the origin. The viscosity of the AN-102 simulant was virtually identical to that of the pretreated (Sr/TRU processed and $\mathrm{Cs}$ and Tc removed) actual waste $\mathrm{AN}-102$ diluted feed. The AN-102 actual waste and the simulant were both Newtonian fluids in rheological behaviors. The average viscosity of the actual AN-102 waste at $6.0 \mathrm{M} \mathrm{Na}$ and $25^{\circ} \mathrm{C}$ was $4.0 \pm 1.0 \mathrm{cP}$, and the average viscosity of the $\mathrm{AN}-102$ simulant at $6.5 \mathrm{M} \mathrm{Na}$ was $3.5 \pm 0.1 \mathrm{cP}$. The difference in error bars was due to the difference in the instruments used to make the measurements. Based upon a comparison of their relative errors, there is no statistical difference between the viscosities of the simulant or the actual waste.

Comparison of the properties of the entrained solids simulant to actual entrained solids has not been performed due to the limited availability of actual AN-102 entrained solids in current samples.

$\mathrm{Sr} / \mathrm{TRU}$ process testing with the $\mathrm{AN}-102$ simulant to compare to the actual $\mathrm{AN}-102$ waste performance is in progress.

\subsection{SIMULANT DEVELOPMENT ORGANIZATION}

The AN-102 diluted supernate and entrained solids simulants were developed at Westinghouse Savannah River Company, Savannah River Technology Center. The primary contact for the simulant development work is: 
Russell Eibling

SRTC

Building 999-W, Room 335

Aiken, SC 29808

Phone: 803-819-8411

FAX: 803-819-8416

Email: russell.eibling@srs.gov

\subsection{REFERENCES}

Townson, PS. 2001. Simulant Definition and Verification Methodology, 24590-WTP-RPTTE-01-003, Rev. 0, River Protection Project Waste Treatment Plant, Richland, WA.

Hay, M. S., Bronikowski, M. G., Hsu, C. W., and T. L. White. July 31, 2000. Chemical Characterization of an Envelope C Sample from Hanford Tank 241-AN-102. USDOE Report BNF-003-98-0250, Rev 0, Savannah River Site, Aiken, SC 29808.

Urie, M. W., Fiskum, S. K., Campbell, J. A., Farmer, O. T., Greenwood, L. R., Hoppe, E. W., Mong, G. M., Soderquist, C. Z., Swoboda, R. G., Thomas, M. P., and J. J. Wagner. July, 2002. Chemical Analysis and Physical Property Testing of 241-AN-102 Tank Waste-Supernatant and Centrifuged Solids. PNWD-3173, WTP-RPT-020, Pacific Northwest National Laboratory, Richland, WA 99352.

Esch, R. A. 1998. Tank 241-AN-102 Low Activity Waste Envelope C Analytical Results for the Final Report. HNF-SD-WM-DP-310, Rev 0, Waste Management Federal Services of Hanford, Inc for Fluor Daniel Hanford, Inc., Richland, WA, 99352.

Jo, J., Morris, B. J., and T. T. Tran. August 1996. Tank Characterization Report for DoubleShell Tank 241-AN-102. WHC-SD-WM-ER-545, Rev 1, Westinghouse Hanford Company, Richland, WA 99352.

Lokken, R.O., Scheele, R. D., Strachan, D. M., and A. P. Toste. September 1986. Complex Concentrate Pretreatment FY 1986 Progress Report. PNL-7687, Pacific Northwest Laboratory, Richland, WA 99352.

Toste, A. P., Lechner-Fish, T. J., Hendren, D. J., Scheele, R. D., and W. G. Richmond. "Analysis of Organics in Highly Radioactive Nuclear Wastes". Journal of Radioanalytical and Nuclear Chemistry, 123, p 149 (1988). 